Article

\title{
Light Absorption Budget in a Reservoir Cascade System with Widely Differing Optical Properties
}

\author{
Nariane Bernardo ${ }^{1}\left(\mathbb{D}\right.$, Enner Alcântara ${ }^{2, *}\left(\mathbb{D}\right.$, Fernanda Watanabe ${ }^{1}\left(\mathbb{D}\right.$, Thanan Rodrigues $\left.{ }^{3}{ }^{(}\right)$, \\ Alisson do Carmo ${ }^{1}{ }^{1}$, Ana Carolina Campos Gomes ${ }^{1}$ and Caroline Andrade ${ }^{1}{ }^{1}$ \\ 1 Department of Cartography, São Paulo State University-UNESP, Presidente Prudente, SP 19060-100, Brazil; \\ narianebernardo@gmail.com (N.B.); fernanda@fct.unesp.br (F.W.); alisondocarmo@gmail.com (A.d.C.); \\ camposgomes.ac@gmail.com (A.C.C.G.); carol.piffer1@gmail.com (C.A.), \\ 2 Department of Environmental Engineering, São Paulo State University-UNESP, São José Dos Campos, \\ SP 12245-000, Brazil \\ 3 Federal Institute of Education, Science and Technology of Pará State-IFPA, Castanhal, PA 68740-970, Brazil; \\ thanan.rodrigues@ifpa.edu.br \\ * Correspondence: enner.alcantara@unesp.br; Tel.: +55-012-99634-1464
}

Received: 9 October 2018; Accepted: 23 January 2019; Published: 29 January 2019

\begin{abstract}
Aquatic systems are complex systems due to the environmental pressures that lead to water quality parameter changes, and consequently, variations in optically active compounds (OAC). In cascading reservoir systems, such as the Tietê Cascade Reservoir System (TCSR), which has a length of $1100 \mathrm{~km}$, the horizontal gradients are expressive due to the filtration process that is caused by the sequence of dams affecting the light absorption throughout the cascade. Our new observations showed that colored dissolved organic matter (CDOM) dominate two reservoirs; non-algae particles (NAP) dominate one, and phytoplankton dominates the other. The variability of light absorption along the cascade indicates the influence of watershed dynamics in the reservoirs as much as the flow driven by previous reservoirs. Despite the effect of the variability of light absorption, light absorption by phytoplankton strongly affects the total absorption in the four reservoirs in TCSR. The results obtained in this work may enable a better understanding of how the gradient pattern changes primary production and indicates a challenge in retrieving OAC concentrations using a bio-optical model for an entire cascade composed of different optical environments.
\end{abstract}

Keywords: light absorption; inland water; water quality monitoring; bio-optical characterization

\section{Introduction}

Water quality monitoring has been efficiently performed via remotely sensed data, using empirical and analytical models, and when applied to time-series images, it provides synoptic scale observations [1-4]. The success of remote sensing applications to aquatic systems depends on the understanding of underwater light interactions with the optically active compounds (OACs) [5]. These interactions are expressed by inherent optical properties (IOPs), the absorption and scattering of light, and the OACs are represented by chlorophyll- $a$ (Chl-a), suspended particulate matter (SPM), and colored dissolved organic matter (CDOM) [5].

Much attention has been devoted to characterizing aquatic systems and determining the spatial variability of IOPs in the ocean [5-9], coastal environments [10-12], and bays [13,14]. For inland waters, efforts have been made to characterize Australian [15], African [16], and Brazilian reservoirs [3,17] to identify the optical differences between open oceans and freshwater systems. The newest studies have also been developed to classify the inland water systems [18-20] and overcome the challenge of bio-optical modeling in such environments [21]. 
Bio-optical modeling is used to create a remotely sensed-based algorithm, which can be applied to satellite images and used to monitor water quality variability over time. In inland waters with specially linked water systems, such as cascading reservoirs, a high variability in optical properties prevents the use of only one model to estimate the water quality parameters. For example, Rodrigues et al. (2017a) studied two reservoirs with widely differing optical properties and tried to estimate the SPM concentration using only one adjusted model. However, this was not possible; each reservoir needed a local model [22]. An understanding of how light is absorbed and how a connected system influences not only the absorption but also the water quality parameters is mandatory for operational monitoring from space. Until now, most studies have investigated and proposed the development of new bio-optical models; however, few studies have aimed to understand light absorption variability and how it has been conducted on cascading systems.

In contrast to open oceans, inland waters are optically complex environments, due to the different influences of OACs [18]. Moreover, inland waters are influenced by internal processes and environmental pressures, such as nutrient enrichment, wastewater discharges, and other non-natural disturbances [23-25]. In cascade reservoir systems, the existence of sequential dams modifies the water retention time of continuous rivers and impacts the filtration process, which changes the OACs concentrations and compositions from upstream to downstream, as predicted by the Cascade Reservoir Continuum Concept (CRCC) [26]. Relying on the OAC's variability in TCSR, a relevant scientific question is raised: what is the behavior of the IOPS throughout cascading reservoirs, since the IOPs are related to the composition and morphology of OACs? We hypothesize that a strong relationship would exist between the concentration of OACs and the absorption properties in aquatic continuum systems, and both would be affected similarly by autochthonous and allochthonous strengths throughout the course of the Tietê River.

Considering its $1100 \mathrm{~km}$ of extension, the Tietê Cascade System Reservoir (TCSR) environment is a challenging and relevant region to investigate, since its water attends to fishery activities, navigation, hydroelectric productivity, and supplies industrial, agriculture, and domestic demands [26,27]. The TCSR's waters are deeply affected by different non-natural contamination sources, such as discharges from pasture waste, wastewater from urban centers, and other agricultural activities developed in nearby areas, including sugarcane and citrus crops [4,28]. As consequence, Barra Bonita (BB) and Bariri (BAR) reservoirs are considered eutrophic environments [29], Ibitinga (IBI) is considered a meso-to-eutrophic $[30,31]$, and Nova-Avanhandava (NAV) is considered an oligo-to-mesotrophic environment [3].

Understanding the optical features throughout long rivers is crucial for a better understanding of the riverine transfers and their potential role in global biogeochemical cycles. Therefore, the present data are suitable to contribute to the understanding of the dynamics of this type of aquatic system, aiming to gain insights into the optical information of South American aquatic continuum systems by sampling the absorption coefficients from non-algal particles (NAP), chlorophyll- $a$ (Chl- $a$ ), and colored dissolved organic matter (CDOM) in TCSR. The specific goals of this work were to analyze the optical properties in an aquatic continuum river, identify whether there was a downstream gradient in spectral absorption, and verify the controls on the light absorption budget. Considering the optical characteristics as well known, remote sensing products can be better used for continuous monitoring and establishing effective control strategies to improve water quality, mainly for larger rivers such as the Tietê River.

\section{Materials and Methods}

\subsection{Study Area}

The Tietê River runs from west to east for $1100 \mathrm{~km}$ in São Paulo State, passing through the capital, and flows into the Paraná River, which is a tributary of the Plata River. There are six hydroelectric reservoirs placed along the Tietê Cascade System of Reservoirs (TCSR) from upstream to downstream. 
They are: $\mathrm{BB}\left(22.50^{\circ} \mathrm{S} ; 48.51^{\circ} \mathrm{W}\right)$, BAR $\left(22.15^{\circ} \mathrm{S} ; 48.73^{\circ} \mathrm{W}\right)$, IBI $\left(21.65^{\circ} \mathrm{S} ; 48.98^{\circ} \mathrm{W}\right)$, Promissão $\left(21.48^{\circ} \mathrm{S}\right.$; $\left.49.83^{\circ} \mathrm{W}\right)$, NAV $\left(22.11^{\circ} \mathrm{S} ; 50.17^{\circ} \mathrm{W}\right)$, and Três Irmãos $\left(20.68^{\circ} \mathrm{S} ; 51.32^{\circ} \mathrm{W}\right)$ (Figure 1 -Datum WGS 84 , geographic coordinate system). BB, BAR, IBI, and NAV reservoirs are responsible for more than $90 \%$ of the hydroelectric productivity from the entire cascade, and present flooded areas of $310 \mathrm{~km}^{2}$, $63 \mathrm{~km}^{2}, 114 \mathrm{~km}^{2}$, and $210 \mathrm{~km}^{2}$, respectively. NAV, IBI, and BAR are run-of-river reservoirs, whilst BB is a storage system.
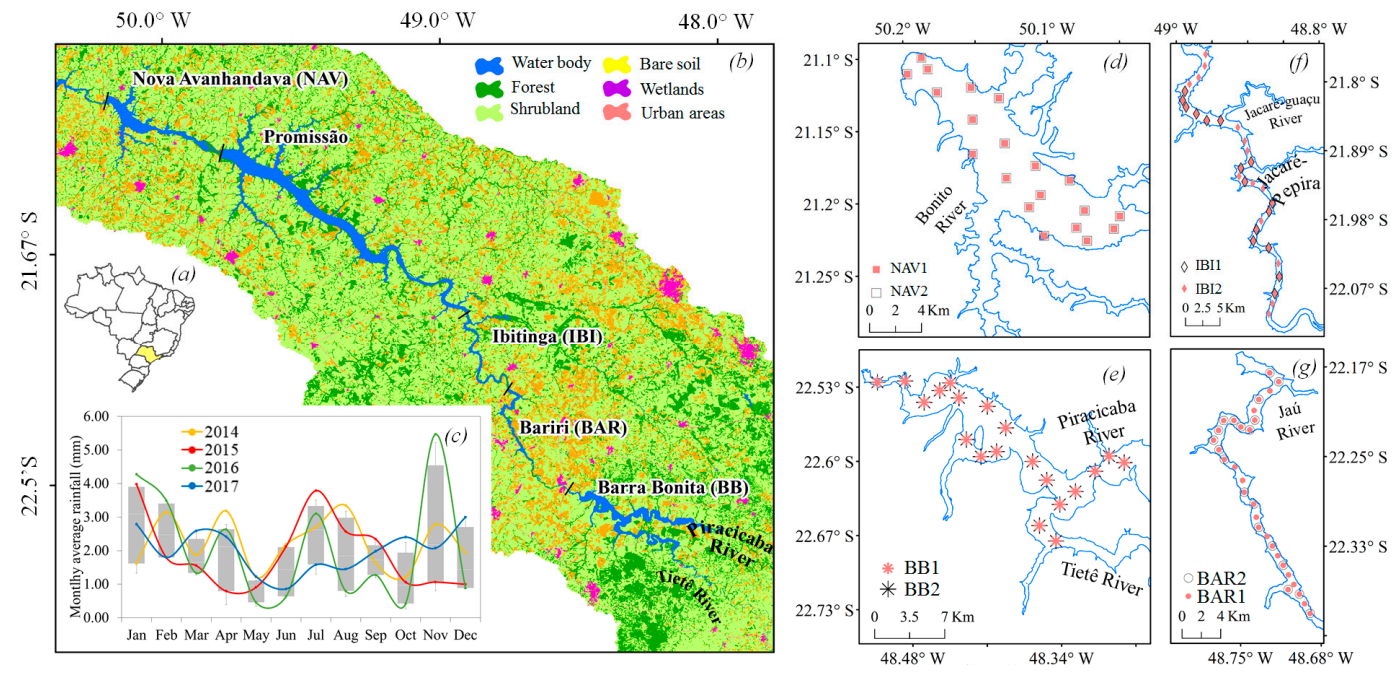

Figure 1. Brazil with São Paulo State location (a); Map of five reservoirs in TCSR (note that Três Irmãos is located after the Nova Avanhandava reservoir) and respective land cover classes of the Tietê Basin (water body, forest, shrubland, bare soil, wetlands, and urban areas by Coordenadoria de Planejamento Ambiental de São Paulo, CPLA, 2010) (b). Monthly average rainfall data from NASA's (National Aeronautics and Space Administration) Giovanni database for the period of 2014-2017 (c); and the sampling locations detailed for each reservoir: NAV1 $(n=20)$ and NAV2 $(n=20)(d)$; BB1 $(n=20)$ and BB2 $(\mathrm{n}=30)(\mathbf{e})$; IBI1 $(\mathrm{n}=10)$ and IBI2 $(\mathrm{n}=20)(\mathbf{f})$; and BAR1 $(\mathrm{n}=30)$ and BAR2 $(\mathrm{n}=18)(\mathrm{g})$. All maps are in WGS84. NAV: Nova-Avanhandava, BB: Barra Bonita, IBI: Ibitinga, and BAR: Bariri.

\subsection{Field Survey}

Eight field campaigns were made in TCSR, with two field studies per reservoir (see details of the sampled locations in Figure 1d-g); therefore, each dataset was labeled with regard to the respective locations and time order: BB1, BB2, NAV1, NAV2, BAR1, BAR2, IBI1, and IBI2. The field studies were carried out between 5-9 May 2014 in BB1; 13-16 October 2014 in BB2; 15-18 August 2016 in BAR1; 23-24 June 2017 in BAR2; 19-23 July 2016 in IBI1; 21-22 June 2017 in IBI2; 28 April to 2 May 2014 in NAV1; and 24-26 September 2014 in NAV2. The date for each fieldwork was established with regard to the Landsat- 8 overpass, to have in situ measurements that were coincident with the satellite data for future applications. Furthermore, all of the field measurements were carried out during the dried periods (Figure 1c), which did not allow us to make seasonal interpretations. Principal component analysis was performed using the standard deviation image, which was retrieved from the temporal series of the Operational Land Imager (OLI) (onboard Landsat-8). The first component of the standard deviation (SD) image was then used to determine the sampling locations within each reservoir (more details are given in [32]).

Physical parameters, such as temperature $\left({ }^{\circ} \mathrm{C}\right)$, turbidity (NTU), and depth $(\mathrm{m})$ were measured in triplicate in all of the sampling locations. The Secchi disk depth $\left(\mathrm{Z}_{\mathrm{SD}}, \mathrm{m}^{-1}\right)$ was achieved with a black and white disk with a 30-cm diameter. Furthermore, water samples were collected near the surface (depth $=0.3 \mathrm{~m}$ ) in five-liter black plastic bottles that were rinsed three times with the water from each sampling spot. To preserve the original features of the samples, the bottles were stored in the dark at low temperatures until laboratory analysis, where absorption spectra measurements were made. 
The SPM and Chl- $a$ concentrations were established following the American Public Health Association (APHA) (1998) and Golterman et al. (1978) protocols [33,34], respectively.

\subsection{Absorption Coefficients}

The IOPs are represented by $a(\lambda)$, scattering coefficients $(b(\lambda))$, and the volume scattering function (VSF). To analyze the optical composition of the cascade system in terms of IOPs, only the absorption spectra measured in situ were assessed in this work. The total absorption spectra $a_{t}(\lambda)$ that resulted from the contribution of each OAC spectrum (Equation (1)) can be mathematically described as follows:

$$
a_{t}(\lambda)=a_{c d o m}(\lambda)+a_{\phi}(\lambda)+a_{n a p}(\lambda)+a_{w}(\lambda),
$$

where $a_{t}(\lambda)$ is the total absorption spectrum, $a_{c d o m}(\lambda)$ is the absorption spectrum of CDOM (Equation (2)), $a_{\phi}(\lambda)$ is the absorption spectrum of phytoplankton (Equation (3)), $a_{n a p}(\lambda)$ is the absorption spectrum of non-algal particles (NAP, Equation (4)), and $a_{w}(\lambda)$ is the absorption spectrum of pure water from Smith and Baker et al. (1981) [35].

All of the absorption coefficients were derived using absorbance readings (ABS) on a SHIMADZU UV-2600 UV-VIS spectrophotometer (SHIMADZU, Japan) with a one-nm spectral resolution, ranging from 280 to $800 \mathrm{~nm}$. The $a_{\text {cdom }}(\lambda)$ was established after water samples were filtered through a nylon membrane with a $47-\mathrm{mm}$ diameter and $0.22-\mu \mathrm{m}$ pore size. The filtrate was placed in quartz cuvettes, with an optical path of $10 \mathrm{~cm}(L=0.1 \mathrm{~m})$. Then, the spectral ABS readings were taken to derive $a_{c d o m}(\lambda)$ after filtration and acclimation to room temperature (Equation (2)):

$$
a_{\text {cdom }}(\lambda)=\frac{2.303 \times A B S(\lambda)}{L},
$$

where $L$ is the optical path length of the cuvette, and ABS is the spectral absorbance reading within 280 to $800 \mathrm{~nm}$ of the interval. Baseline data were obtained by using Milli- $Q$ water placed in a $10-\mathrm{cm}$ quartz cuvette. The conversion factor (2.303) between the base 10 logarithm and natural logarithm was used, and was applied to the baseline correction by subtracting the residual absorbance, i.e., the average value between $700-750 \mathrm{~nm}$. The $a_{\text {cdom }}$ spectra were established by the methodology proposed by Bricaud et al. (1981) [6], and the fit of the exponential function was also computed to achieve the $S_{c d o m}$ results [9].

To compute $a_{\text {nap }}$ and $a_{\phi}$, water samples were filtered through fiberglass filters (Whatman GF/F with a 0.7 pore size and $47-\mathrm{mm}$ diameter), placed inside the integrated sphere module using a blank filter as reference, and then wetted with drops of Milli-Q water during the laboratory analysis [16]. The transmittance and reflectances were read to compute the particulate absorption $\left(a_{p}\right)$, following the transmittance-reflectance method [36,37].

The bleaching of the organic fraction of SPM was performed using hypochlorite solution $(\mathrm{NaClO})$ at $10 \%$. The bleached filters were washed with Milli-Q water to prevent the eventual contamination of the remaining $\mathrm{NaClO}$, and new transmittances and reflectances readings were made to compute $a_{\text {nap }}$. The $a_{\phi}$ was achieved by subtracting $a_{\text {nap }}$ from $a_{p}$ (Equations (3) and (4)):

$$
\begin{gathered}
a_{\phi}(\lambda)=a_{p}(\lambda)-a_{\text {nap }}(\lambda) \\
a_{\text {nap }}(\lambda)=a_{\text {nap }}\left(\lambda_{0}\right) \times e^{-S_{\text {nap }}\left(\lambda-\lambda_{0}\right)}
\end{gathered}
$$

where $S_{\text {nap }}$ is the slope of the exponential decreasing function considering a spectral range (the present study uses 400 to $700 \mathrm{~nm}$ ), which mathematically describes the relative steepness of the curve [38], and $\lambda_{0}$ is the reference wavelength, which is usually adopted near $443 \mathrm{~nm}$ for $a_{c d o m}$ and $a_{\text {nap }}$. To avoid systematic errors due to different methodologies, all of the absorption values were established following specific protocols for each OAC. 


\section{Results}

\subsection{Water Quality Scenery}

The descriptive statistics of water quality parameters measured in situ are summarized in Table 1. In BB (both campaigns), particulate inorganic matter (PIM) presented the highest variation, with $\mathrm{CV}=78.8 \%$ and $37.3 \%$, respectively. BAR1 showed the highest variation in $\mathrm{Chl}-a(\mathrm{CV}=80.5 \%)$, while BAR2 presented the highest variation for PIM $(\mathrm{CV}=42.9 \%)$. In IBI (both campaigns), the larger variability resulted from Chl- $a(\mathrm{CV}=86.0 \%$ and $67.8 \%)$, and for NAV (both campaigns), the larger variability was obtained in PIM ( $\mathrm{CV}=76.8 \%$ and $65.8 \%$, respectively). The lowest variability resulted from temperature for all of the field studies, with CV comprising between 1.90-15.4\%.

Table 1. Descriptive statistics of water quality parameters in BB, BAR, IBI, and NAV from two field campaigns. Here Min, Max, SD, and CV represent the minimum, maximum, standard deviation, and coefficient of variation (in \%), respectively. Zsd is the Secchi Disk Depth (m), SPM is suspended particle matter $\left(\mathrm{mg} \cdot \mathrm{L}^{-1}\right)$, PIM is particulate inorganic matter $\left(\mathrm{mg} \cdot \mathrm{L}^{-1}\right)$, POM is particulate organic matter $\left(\mathrm{mg} \cdot \mathrm{L}^{-1}\right), \mathrm{Chl}-a$ is Chlorophyll- $a$ concentration $\left(\mathrm{mg} \cdot \mathrm{m}^{-3}\right)$, and Temp is temperature $\left({ }^{\circ} \mathrm{C}\right)$.

\begin{tabular}{|c|c|c|c|c|c|c|c|c|}
\hline & $\mathrm{Z}_{\mathrm{sd}}(\mathrm{m})$ & $\begin{array}{l}\text { Turbidity } \\
\text { (NTU) }\end{array}$ & $\mathrm{pH}$ & $\begin{array}{c}\text { Chl- } a \\
\left(\mathrm{mg} \cdot \mathrm{m}^{-3}\right)\end{array}$ & $\begin{array}{c}\mathrm{SPM} \\
\left(\mathrm{mg} \cdot \mathrm{L}^{-1}\right)\end{array}$ & $\begin{array}{c}\text { PIM } \\
\left(\mathrm{mg} \cdot \mathrm{L}^{-1}\right)\end{array}$ & $\begin{array}{c}\text { POM } \\
\left(\mathrm{mg} \cdot \mathrm{L}^{-1}\right)\end{array}$ & $\begin{array}{l}\text { Temp. } \\
\left({ }^{\circ} \mathrm{C}\right)\end{array}$ \\
\hline \multicolumn{9}{|c|}{ Barra Bonita $1(n=20)-B B 1$} \\
\hline Min & 0.80 & 1.66 & 7.18 & 17.75 & 3.60 & 0.20 & 2.80 & 24.5 \\
\hline $\operatorname{Max}$ & 2.30 & 12.50 & 9.25 & 279.86 & 16.30 & 4.40 & 14.7 & 26.9 \\
\hline Mean & 1.49 & 5.17 & 8.36 & 120.44 & 7.21 & 1.10 & 6.10 & 25.6 \\
\hline$C V$ & 28.9 & 47.0 & 8.32 & 58.4 & 45.21 & 78.8 & 52.0 & 2.8 \\
\hline \multicolumn{9}{|c|}{ Barra Bonita $2(n=20)-B B 2$} \\
\hline Min & 0.37 & 11.60 & 7.12 & 263.20 & 10.80 & 0.60 & 10.2 & 24.5 \\
\hline $\operatorname{Max}$ & 0.78 & 33.20 & 10.1 & 797.80 & 44.00 & 3.80 & 30.4 & 32.1 \\
\hline Mean & 0.57 & 18.64 & 9.28 & 428.72 & 21.97 & 2.60 & 18.2 & 28.1 \\
\hline$C V$ & 17.18 & 28.26 & 9.44 & 36.03 & 32.05 & 37.30 & 26.2 & 7.8 \\
\hline \multicolumn{9}{|c|}{ Bariri $(n=30)-B A R 1$} \\
\hline Min & 0.50 & 7.80 & 6.10 & 25.67 & 3.60 & 0.90 & 1.4 & 21.1 \\
\hline $\operatorname{Max}$ & 1.60 & 80.90 & 9.90 & 709.89 & 40.33 & 4.00 & 36.3 & 39.4 \\
\hline Mean & 1.16 & 16.60 & 7.90 & 119.76 & 8.28 & 2.30 & 5.9 & 24.3 \\
\hline$C V$ & 20.03 & 45.82 & 10.5 & 80.52 & 54.76 & 21.4 & 75.1 & 15.4 \\
\hline \multicolumn{9}{|c|}{ Bariri $(n=18)-B A R 2$} \\
\hline Min & 1.60 & 3.50 & 6.83 & 3.80 & 0.20 & 0.20 & 0.40 & 22.0 \\
\hline $\operatorname{Max}$ & 3.20 & 8.80 & 7.28 & 19.0 & 2.60 & 1.30 & 1.60 & 23.9 \\
\hline Mean & 2.20 & 5.7 & 6.97 & 8.00 & 1.60 & 0.60 & 1.10 & 22.8 \\
\hline$C V$ & 10.9 & 21.9 & 1.90 & 40.9 & 27.90 & 42.4 & 28.8 & 1.90 \\
\hline \multicolumn{9}{|c|}{ Ibitinga $(n=30)-I B I 1$} \\
\hline Min & 1.60 & 2.82 & 5.50 & 1.37 & 1.00 & 0.30 & 0.50 & 21.2 \\
\hline $\operatorname{Max}$ & 3.20 & 8.87 & 7.00 & 119.04 & 8.10 & 2.60 & 6.00 & 30.1 \\
\hline Mean & 2.23 & 4.29 & 6.10 & 21.75 & 2.61 & 0.80 & 1.80 & 23.7 \\
\hline$C V$ & 10.91 & 17.90 & 6.80 & 85.97 & 39.20 & 35.3 & 49.6 & 9.50 \\
\hline \multicolumn{9}{|c|}{ Ibitinga $(n=16)-I B I 2$} \\
\hline Min & 1.90 & 1.85 & 6.50 & 2.50 & 0.20 & 0.20 & 0.30 & 21.40 \\
\hline $\operatorname{Max}$ & 3.80 & 3.60 & 6.96 & 13.7 & 2.20 & 1.00 & 1.90 & 24.00 \\
\hline Mean & 2.90 & 2.47 & 6.78 & 6.64 & 1.06 & 0.40 & 0.93 & 22.82 \\
\hline$C V$ & 19.5 & 21.1 & 1.77 & 67.2 & 53.5 & 61.8 & 49.8 & 3.80 \\
\hline
\end{tabular}


Table 1. Cont.

\begin{tabular}{|c|c|c|c|c|c|c|c|c|}
\hline & $\mathrm{Z}_{\mathrm{sd}}(\mathrm{m})$ & $\begin{array}{c}\text { Turbidity } \\
\text { (NTU) }\end{array}$ & $\mathrm{pH}$ & $\begin{array}{c}\text { Chl- } a \\
\left(\mathrm{mg} \cdot \mathrm{m}^{-3}\right)\end{array}$ & $\begin{array}{c}\mathrm{SPM} \\
\left(\mathrm{mg} \cdot \mathrm{L}^{-1}\right)\end{array}$ & $\begin{array}{c}\text { PIM } \\
\left(\mathrm{mg} \cdot \mathrm{L}^{-1}\right)\end{array}$ & $\begin{array}{c}\text { POM } \\
\left(\mathrm{mg} \cdot \mathrm{L}^{-1}\right)\end{array}$ & $\begin{array}{l}\text { Temp. } \\
\left({ }^{\circ} \mathrm{C}\right)\end{array}$ \\
\hline \multicolumn{9}{|c|}{ Nova Avanhandava $1(n=20)-N A V 1$} \\
\hline Min & 2.29 & 1.01 & 8.50 & 2.46 & 0.10 & 0.10 & 0.20 & 25.1 \\
\hline $\operatorname{Max}$ & 4.80 & 2.47 & 8.90 & 12.56 & 2.60 & 2.20 & 0.90 & 26.3 \\
\hline Mean & 3.15 & 1.66 & 8.60 & 6.21 & 1.01 & 0.70 & 0.93 & 26.0 \\
\hline$C V$ & 19.95 & 25.40 & 1.39 & 40.0 & 61.7 & 76.7 & 40.8 & 1.12 \\
\hline \multicolumn{9}{|c|}{ Nova Avanhandava $2(n=20)-N A V 2$} \\
\hline Min & 2.45 & 1.01 & 7.60 & 4.51 & 0.50 & 0.14 & 0.30 & 23.8 \\
\hline $\operatorname{Max}$ & 4.65 & 2.56 & 8.30 & 20.5 & 2.80 & 2.00 & 1.10 & 25.6 \\
\hline Mean & 3.41 & 1.73 & 8.10 & 9.01 & 1.00 & 0.50 & 0.50 & 24.6 \\
\hline$C V$ & 14.1 & 18.98 & 2.20 & 34.9 & 37.6 & 65.8 & 26.5 & 1.90 \\
\hline \multicolumn{9}{|c|}{ Entire Dataset $(n=174 *)$} \\
\hline Min & 0.37 & 1.01 & 5.50 & 1.37 & 0.10 & 0.08 & 0.20 & 21.1 \\
\hline $\operatorname{Max}$ & 4.80 & 80.9 & 10.1 & 797.80 & 44.00 & 4.40 & 43.00 & 39.4 \\
\hline Mean & 1.15 & 13.31 & 8.36 & 197.50 & 11.34 & 1.94 & 9.40 & 25.8 \\
\hline$C V$ & 88.7 & 67.0 & 13.9 & 80.0 & 69.7 & 53.1 & 81.0 & 10.8 \\
\hline
\end{tabular}

The TCSR showed $\mathrm{pH}$ values ranging between 5.50 (IBI2) and 10.1 (BB2), and the temperature ranged from $21.1{ }^{\circ} \mathrm{C}$ to $39.4{ }^{\circ} \mathrm{C}$. The highest SPM and Chl- $a$ concentrations varied between three orders of magnitude in TCSR, whereas PIM varied between two orders of magnitude. BB2 reached the maximum concentrations (SPM $=44.0 \mathrm{mg} \cdot \mathrm{L}^{-1}$ and $\mathrm{Chl}-a=797.8 \mathrm{mg} \cdot \mathrm{m}^{-3}$ ), whilst NAV1 reached the lowest SPM concentration (SPM $=0.1 \mathrm{mg} \cdot \mathrm{L}^{-1}$ ). The lowest Chl- $a$ concentration was found in IBI1 $\left(\mathrm{Chl}-a=1.4 \mathrm{mg} \cdot \mathrm{m}^{-3}\right)$. The full TCSR dataset demonstrated high correlations between Chl $a$ and SPM concentrations, with $\mathrm{r}=0.95$ ( $p$-value $<0.05$ ). It is important to note that the Chl- $a$ and particulate organic matter (POM) fractions showed $r=0.94$ ( $p$-value $<0.05$, plot is not depicted here), whilst the SPM and POM fractions showed $\mathrm{r}=0.99$ ( $p$-value $<0.05)$. The SPM and PIM concentrations also showed significant statistical relations $(\mathrm{r}=0.67, p$-value $<0.05)$.

The PIM and POM concentrations showed an organic-to-inorganic standard from upstream to downstream reservoirs. Although the average proportions are similar between all of the reservoirs (Figure S1), we observed expressive POM concentrations in BB and BAR compared to PIM concentrations, as well as the expressive PIM concentrations in NAV (Table 2) compared to POM concentrations. Details about the inorganic-to-organic relation along the cascade reservoirs are presented in the Supplementary Materials (Figure S1).

Inverse relationships were observed between water transparency (represented by $Z_{\mathrm{SD}}$ ) against Chl- $a$, as well as the $Z_{S D}$ against PIM, $Z_{S D}$ against $S P M$, and $Z_{S D}$ against POM. Through the cascade, the $\mathrm{Z}_{\mathrm{SD}}$ was slightly more influenced by SPM, with $\mathrm{r}=0.70$ ( $p$-value $\left.<0.05\right)$ than Chl- $a$, PIM, and POM $\left(r=0.66,0.66\right.$, and 0.69 , respectively). The minimum value of $Z_{S D}$ was obtained in BB2 $(=0.37 \mathrm{~m})$, and the maximum was found in NAV1 $(=4.80 \mathrm{~m})$. Overall, the downstream reservoirs (NAV and IBI) presented higher $Z_{S D}$, and the upstream reservoirs (BB and BAR) showed lower $Z_{S D}$ values.

The boxplots (Figure 2) illustrated the water quality parameter gradients throughout the cascade system. High SPM concentrations were accomplished by the high Chl- $a$ concentrations in upstream reservoirs (BB and BAR reservoirs in Figure 2a,b). The turbidity (Figure 2c) decays from upstream to downstream (from BB to NAV), following the SPM and Chl- $a$ concentration behaviors. The $Z_{\mathrm{SD}}$ is lower in reservoirs with high turbidity, and it is higher in reservoirs with low turbidity, as expected (Figure 2d). Although the reservoirs demonstrated the interconnection process, the temperature and $\mathrm{pH}$ did not present any detectable pattern (boxplots are not shown). 

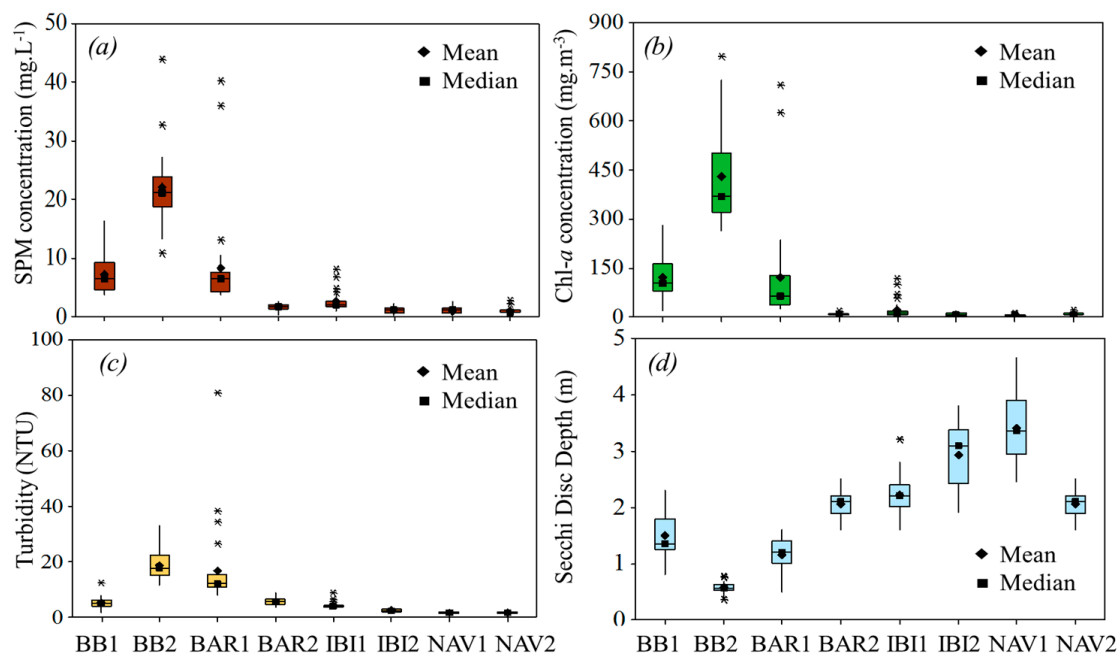

Figure 2. Boxplot of water quality parameters obtained in each field campaigns: (a) SPM concentration $\left(\mathrm{mg} \cdot \mathrm{L}^{-1}\right)$; (b) Chl- $a$ concentrations $\left(\mathrm{mg} \cdot \mathrm{m}^{-3}\right)$; (c) Turbidity (NTU); (d) Secchi disk depth (Z $\mathrm{SD}_{\mathrm{SD}}$ meters).

\subsection{Absorption Spectra}

\subsubsection{Absorption by CDOM}

The CDOM absorption spectral curves for the TCSR dataset $\left(a_{c d o m}(\lambda)\right)$, with 175 sampling spots, are depicted in Figure 3a, which followed the exponential fit, as expected.
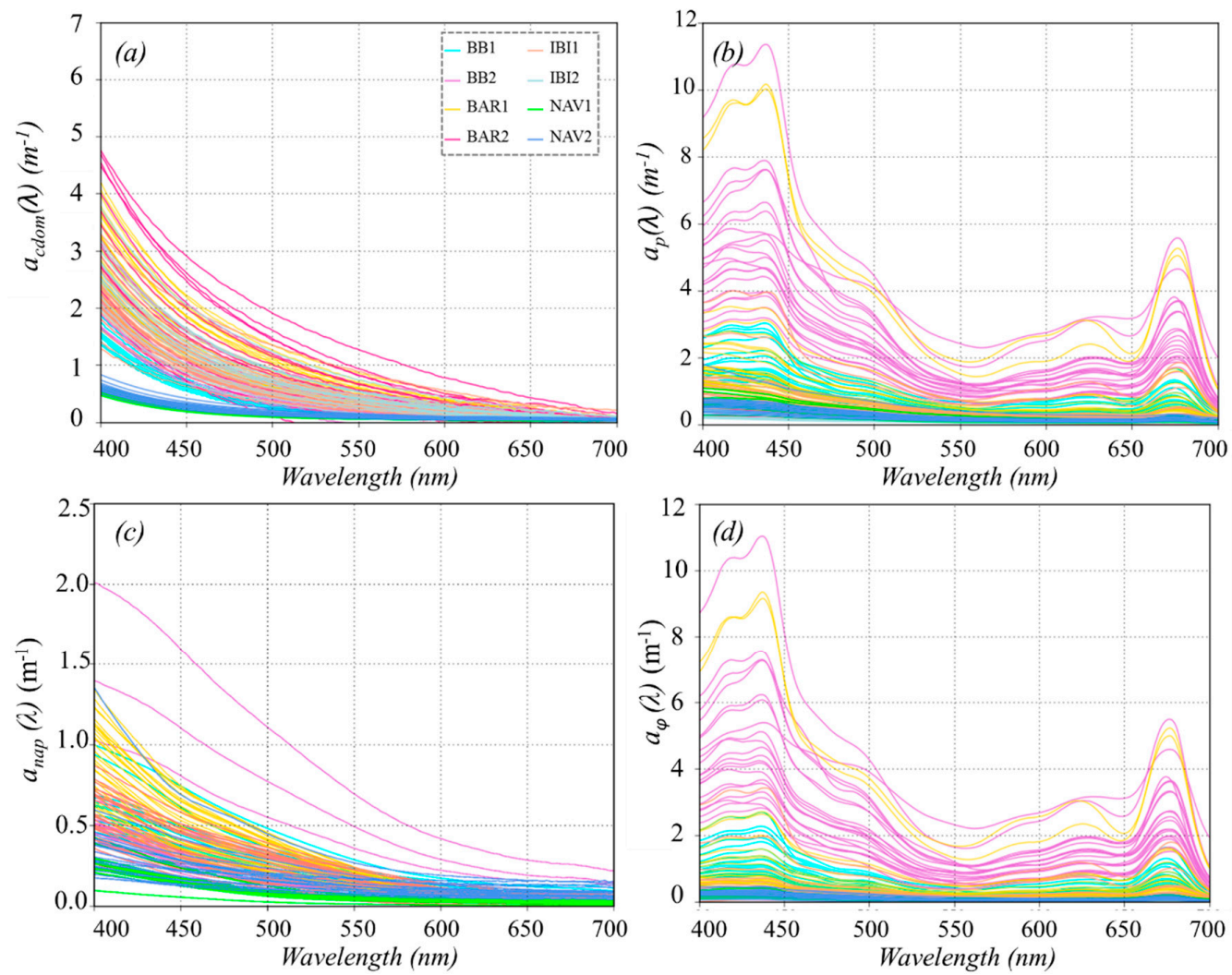

Figure 3. In situ absorption spectra from all of the sampling locations for (a) $a_{\mathrm{cdom}}$; (b) $a_{\mathrm{p}}$; (c) $a_{\text {nap }}$; and (d) $a_{\phi}$.

Regarding the TCSR values, the $a_{\text {cdom }}(443)$ ranged from $0.21 \mathrm{~m}^{-1}$ (NAV1) to $3.17 \mathrm{~m}^{-1}$ (BAR2), as shown in Table 2. The assessment of the coefficient of variation (CV) depicted BAR2 as having the 
highest $a_{c d o m}(443)$ variability $(\mathrm{CV}=33.2 \%)$, and NAV1 as having the lowest variability $(\mathrm{CV}=8.5 \%)$. To quantify the distinct decay between the fieldwork, the slopes of CDOM $\left(S_{c d o m}\right)$ were calculated by fitting an exponential function and non-linear least squares method. Scdom comprised between 0.004 (in BB2) and $0.020 \mathrm{~nm}^{-1}$ (in NAV2) (Table 3). Although the $S_{c d o m}$ range for BB1, NAV1, and NAV2 are similar (0.016-0.018; 0.014-0.017; and 0.016-0.020 $\left.\mathrm{nm}^{-1}\right)$, a paired t-test showed that the $S_{c d o m}$ values are different at $5 \%$ of significance. The same conclusion was obtained from comparisons between BB2 versus BB1, NAV1, NAV2, and between BAR1 versus IBI1.

Table 2. Descriptive statistics of $a_{p}(443)$ in $\mathrm{m}^{-1}, a_{\phi}(443), a_{\text {nap }}(443), a_{c d o m}(443)$, non-algae particles (NAP) Slope $\left(S_{\text {nap }}\right)$, and colored dissolved organic matter $(\mathrm{CDOM})$ Slope $\left(S_{\text {cdom }}\right)$. Where Max, Min, SD, and CV are the maximum, minimum, standard deviation, and coefficient of variation (in \%). The exponential slope was obtained from CDOM within the 400-700 nm of range.

\begin{tabular}{|c|c|c|c|c|c|c|c|c|c|}
\hline \multicolumn{10}{|c|}{ Field Sites } \\
\hline & & BB1 & BB2 & BAR1 & BAR2 & IBI1 & IBI2 & NAV1 & NAV2 \\
\hline \multirow{4}{*}{$a_{p}(443)$} & Min & 0.69 & 03.12 & 0.70 & 0.16 & 0.23 & 0.12 & 0.10 & 0.24 \\
\hline & $\operatorname{Max}$ & 2.94 & 11.2 & 9.98 & 0.42 & 3.94 & 0.34 & 0.54 & 1.20 \\
\hline & Mean & 1.67 & 5.15 & 1.99 & 0.30 & 0.80 & 0.21 & 0.22 & 0.52 \\
\hline & $\mathrm{CV}$ & 38.90 & 27.10 & 64.70 & 25.90 & 54.10 & 38.40 & 60.40 & 25.60 \\
\hline \multirow{4}{*}{$a_{\phi}(443)$} & Min & 0.29 & 2.77 & 0.34 & 0.04 & 0.06 & 0.05 & 0.02 & 0.06 \\
\hline & Max & 2.62 & 10.9 & 9.19 & 0.20 & 3.41 & 0.14 & 0.18 & 0.44 \\
\hline & Mean & 1.21 & 4.67 & 1.41 & 0.12 & 0.42 & 0.09 & 0.06 & 0.25 \\
\hline & $\mathrm{CV}$ & 52.30 & 31.90 & 64.70 & 28.20 & 89.50 & 33.30 & 72.80 & 31.80 \\
\hline \multirow{4}{*}{$a_{\text {nap }}(443)$} & Min & 0.32 & 0.23 & 0.34 & 0.09 & 0.15 & 0.06 & 0.03 & 0.14 \\
\hline & Max & 0.80 & 1.70 & 0.84 & 0.26 & 0.63 & 0.20 & 0.38 & 0.78 \\
\hline & Mean & 0.47 & 0.49 & 0.58 & 0.18 & 0.39 & 0.12 & 0.12 & 0.27 \\
\hline & $\mathrm{CV}$ & 25.30 & 76.50 & 22.70 & 25.90 & 27.40 & 48.30 & 71.20 & 34.00 \\
\hline \multirow{4}{*}{$a_{\text {cdom }}(443)$} & Min & 0.45 & 0.77 & 1.12 & 0.32 & 0.72 & 0.77 & 0.26 & 0.24 \\
\hline & Max & 0.97 & 1.35 & 2.46 & 3.17 & 2.23 & 2.29 & 0.54 & 0.47 \\
\hline & Mean & 0.83 & 1.05 & 1.71 & 1.84 & 1.29 & 1.35 & 0.26 & 0.32 \\
\hline & $\mathrm{CV}$ & 13.2 & 16.6 & 20.2 & 33.1 & 17.3 & 38.1 & 8.5 & 12.6 \\
\hline \multirow{4}{*}{$S_{c d o m}$} & Min & 0.016 & 0.004 & 0.010 & 0.009 & 0.006 & 0.011 & 0.014 & 0.016 \\
\hline & Max & 0.018 & 0.016 & 0.015 & 0.019 & 0.013 & 0.015 & 0.017 & 0.020 \\
\hline & Mean & 0.017 & 0.012 & 0.012 & 0.013 & 0.009 & 0.013 & 0.015 & 0.018 \\
\hline & $\mathrm{CV}$ & 3.2 & 19.6 & 10.2 & 10.9 & 23.8 & 8.8 & 4.5 & 5.7 \\
\hline \multirow{4}{*}{$S_{\text {nap }}$} & Min & 0.008 & 0.006 & 0.010 & 0.009 & 0.008 & 0.005 & 0.008 & 0.003 \\
\hline & Max & 0.011 & 0.009 & 0.012 & 0.011 & 0.014 & 0.022 & 0.011 & 0.007 \\
\hline & Mean & 0.009 & 0.008 & 0.011 & 0.010 & 0.010 & 0.013 & 0.009 & 0.005 \\
\hline & $\mathrm{CV}$ & 7.90 & 9.40 & 3.90 & 4.10 & 11.60 & 38.60 & 6.70 & 16.70 \\
\hline
\end{tabular}

Regarding the frequency for all of the $S_{c d o m}$ values, the highest frequency was found in the $0.010-0.014 \mathrm{~nm}^{-1}$ range (Figure S2a). Moreover, investigations about relationships between $S_{c d o m}$ and $a_{\text {cdom }}(443)$ demonstrated statistically significant relationships in BB (both field studies) and IBI2 (Figure S2b-d), with $r$ values of $-0.64,-0.87$, and -0.48 , respectively. Other fieldwork showed weaker relationships, such as IBI1 $(\mathrm{r}=0.45)$ and NAV1 $(\mathrm{r}=-0.37)$. BAR (both field studies) and NAV2 did not indicate a statistical relationship between $a_{c d o m}(443)$ and $S_{c d o m}$.

The relations between $a_{c d o m}(443)$ versus Chl- $a$ concentrations, and $a_{c d o m}(443)$ versus SPM concentrations, were also investigated. Considering the entire TCSR dataset, Chl- $a$ and $a_{\text {cdom }}(443)$ presented coefficients of correlation where $-\mathrm{r}=0.15$ ( $p$-value $<0.05)$. However, taking into account each dataset separately, the relationships changes, with BB1, BAR2, IBI2, and NAV2 (Figure S3) showing significant relationships at $5 \%$ significance $(r=0.77,0.66,0.51,0.61$, respectively). Other field studies did not show relationships with statistical significance (BB2, BAR1, IBI1, and NAV1).

Considering SPM and $a_{c d o m}(443)$ relationships, the entire TCSR dataset showed $\mathrm{r}=0.20$ ( $p$-value $<$ 0.05). This scenery changes when field campaigns were individually considered. BB1, IBI1, and NAV1 showed $r=0.54,0.49$, and -0.06 ( $p$-value $<0.05$ ), respectively (graphs are not shown here). The other fields (BB2, BAR1, BAR2, IBI2, and NAV2) did not show significant relationships between SPM and $a_{\text {cdom }}(443)$. 


\subsubsection{Absorption by Particulate Matter}

All of the sampled particulate absorption spectra, $a_{p}(\lambda)$ are plotted in Figure $3 b$, and demonstrated time-fold variation, with the highest magnitudes in BB2, BAR1, and BB1. The lowest magnitudes were found in BAR2 and IBI2. Considering inorganic and organic particle composition, it is worth highlighting that the phytoplankton absorption contributions to the $a_{p}(\lambda)$ curves were mainly in BB (both field studies), due to the absorption features at $443 \mathrm{~nm}$ and $675 \mathrm{~nm}$. In contrast, the inorganic absorption contribution can be highlighted in NAV (both field studies), due to the exponential shape of the absorption curves.

The values of $a_{p}(443)$ for the TCSR dataset ranged from $0.10 \mathrm{~m}^{-1}$ to $11.2 \mathrm{~m}^{-1}$ (see Table 2 for details). The highest variability was found in BAR1 $(\mathrm{CV}=65 \%)$, and the lowest variability was encountered in NAV2 $(\mathrm{CV}=26 \%)$. In addition to the $a_{p}$ curves, inorganic and organic particulate contributions were also evaluated by plotting the NAP $\left(a_{\text {nap }}(\lambda)\right)$ and phytoplankton $\left(a_{\phi}(\lambda)\right)$ absorption spectra (Figure $3 c, d$, respectively).

The absorption of blue light $\left(a_{\phi}(443)\right)$ decreased markedly from the upstream site BB2 $\left(10.9 \mathrm{~m}^{-1}\right)$ to the downstream site NAV1 $\left(0.02 \mathrm{~m}^{-1}\right)$ (Table 2$)$. The $a_{\text {nap }}(\lambda)$ curves did not present the same standard from upstream to downstream, with $a_{\text {nap }}(443)$ ranging between $0.03 \mathrm{~m}^{-1}$ (NAV1) and $1.7 \mathrm{~m}^{-1}$ (BB2) (Table 2).

Two highlighted absorption features are observed in Figure 3d: one at $443 \mathrm{~nm}$ and another at $675 \mathrm{~nm}$, which are due to Chl- $a$ absorption. The highest magnitude of phytoplankton absorption was found in BB2, with $a_{\phi}(443)=10.9 \mathrm{~m}^{-1}$, and $a_{\phi}(675)=5.44 \mathrm{~m}^{-1}$ (Table 2). The lowest magnitudes were found in NAV1 $\left(a_{\phi}(443)=0.02 \mathrm{~m}^{-1}\right)$ and BAR2 $\left(a_{\phi}(675)=0.004 \mathrm{~m}^{-1}\right)$. IBI1 depicted the highest variability among all of the field sites, with $\mathrm{CV}_{443 \mathrm{~nm}}=90 \%$ and $\mathrm{CV}_{675 \mathrm{~nm}}=95 \%$.

Some fieldwork (IBI2, NAV1, and NAV2) did not show statistically significant relationships between Chl- $a$ concentration and $a_{\phi}(443)$ or $a_{\phi}(675)$. BB1, BAR1, and IBI1 presented high relationships, and did not vary the relation with wavelength $(\mathrm{r}=0.90, \mathrm{r}=0.99$, and $\mathrm{r}=0.89$, respectively at $443 \mathrm{~nm}$ and $675 \mathrm{~nm}$ ). In BB2 and BAR2 fieldwork, relationships showed slight differences at each wavelength: at $443 \mathrm{~nm}, \mathrm{BB} 2$ presented $\mathrm{r}=0.64$ and BAR2 presented $\mathrm{r}=0.43$; whereas at $675 \mathrm{~nm}, \mathrm{BB} 2$ presented $\mathrm{r}=$ 0.54 and BAR2 presented $r=0.65$ (BB2 and BAR2 plots can be found in Supplementary Information, Figure S4).

Regarding $a_{\text {nap }}(\lambda)$ curves (Figure $3 c$ ), the exponential shape is a result of the isolation of residual pigment absorptions [9]. This means that there were neither phytoplankton nor accessory pigments features in the $a_{\text {nap }}$ spectra. Among all of the field campaigns, only BAR1 and BAR2 depicted a remarkable change in magnitude for the entire spectrum dataset, demonstrating a considerable division between the two datasets (two to three times the magnitude of difference). IBI1 and IBI2 presented a slight overlap of some curves (the lowest curves for IBI1 overlap the highest curves for IBI2). Overall, BB1 and BB2, and NAV1 and NAV2 presented high similarity among the curves, except for some samples that presented the highest magnitudes.

In terms of magnitude, BB2 showed the highest values for the entire spectra, and NAV1 showed the lowest magnitude (Figure 3c). Among all of the field sites, the largest variability of $a_{\text {nap }}(443)$ was encountered in BB2, with CV $=77 \%$, and the smallest variability was in BAR1, with CV $=23 \%$ (Table 2).

The entire cascade presented Snap values ranging between $0.003-0.023 \mathrm{~m}^{-1}$. Statistical analysis for $S_{\text {nap }}$ (Table 2) demonstrated that IBI2 presented the highest variability $\left(0.005 \mathrm{~nm}^{-1}<S_{\text {nap }}<0.022 \mathrm{~nm}^{-1}\right.$, and $C V=39 \%$ ), and the lowest variability was found in BAR (both fieldworks with CV $=4 \%$ ). The frequency for the entire dataset of $S_{\text {nap }}$ values was analyzed and showed a normal distribution, with the highest frequency in the $0.008-0.010 \mathrm{~m}^{-1}$ range. The relationships between $a_{\text {nap }}(443)$ and PIM concentrations were evaluated, and a statistical relationship was found only in BAR1, with $r=0.50$ $(p$-value $<0.05)$. 


\subsection{Relative Contribution of $O A C^{\prime}$ 's Absorptions in TCSR}

The $a_{t}$ curves represent the sum of all of the individual OAC's absorption spectra with the pure water absorption curve $\left(a_{w}(\lambda)\right.$, Smith and Baker, 1981), as described Equation (1). To identify each OAC absorption contribution to the total absorption without water $\left(a_{t-w}\right)$, the average curves are plotted in Figure 4.
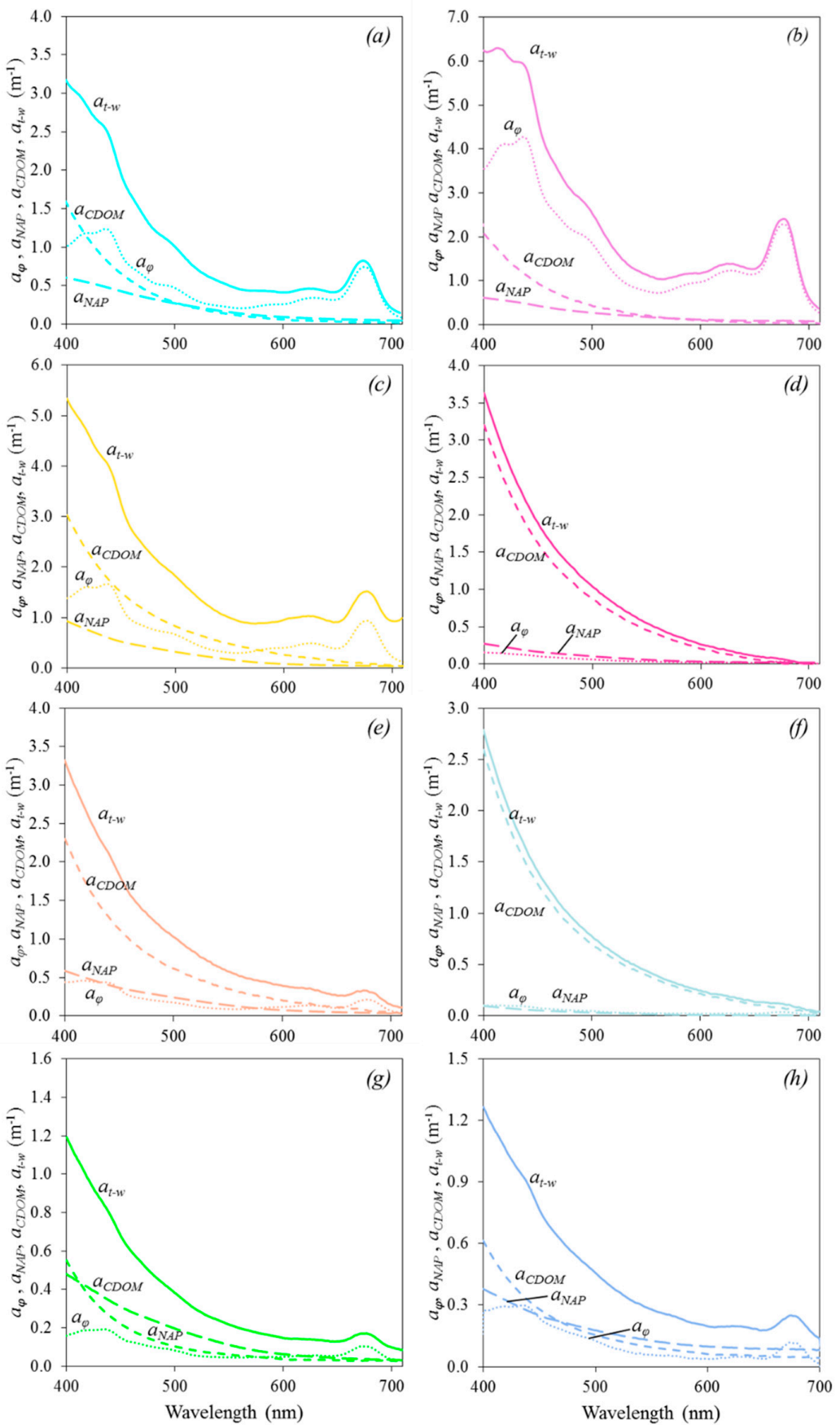

Figure 4. Average absorption coefficients by CDOM ( $a_{c d o m}$, high dashed line), phytoplankton $\left(a_{\phi}\right.$, dotted line), non-algae particles ( $a_{\text {nap }}$, low dashed line), and total non-water absorption ( $a_{t-w}$, continuous line) for the (a) BB1; (b) BB2; (c) BAR1; (d) BAR2; (e) IBI1; (f) IBI2; (g) NAV1; and (h) NAV2. Note the differences in the $\mathrm{Y}$-axis between the surveys. 
Regarding $a_{t-w}$, the BB (both field studies) dataset is markedly influenced by $a_{\phi}$. BAR1 and BAR2 are distinctly different: BAR1 showed absorption features near $443 \mathrm{~nm}, 620 \mathrm{~nm}$, and $675 \mathrm{~nm}$, resulting from $a_{\phi}$ contributions, while BAR2 presented a continuous exponential decrease along the spectra (Figure 4c,d). IBI1 presented smoothed features near $443 \mathrm{~nm}$ and $620 \mathrm{~nm}$, which were derived from $a_{\phi}$ contributions (Figure 4e), whilst IBI2 presented an exponential decrease (Figure 4f). NAV1 and NAV2 (Figure $4 \mathrm{~g}, \mathrm{~h}$ ) depicted an exponential decrease with $a_{n a p}$ and $a_{c d o m}$ contributions up to $670 \mathrm{~nm}$, where $a_{\phi}$ became expressive. NAV1 showed the $a_{\text {nap }}$ predominance, and NAV2 presented a main contribution from $a_{c d o m}$, mainly up to $450 \mathrm{~nm}$.

To compare the spectral behavior throughout the cascade, Figure 4 was reorganized in comparative graphs, as shown in Figure 5. The magnitude of $a_{\phi}(\lambda)$ (Figure 5a) coincides with the order of reservoirs, since the magnitudes followed in the sequence of BB2, BAR1, BB1, IBI1, NAV2, and the remainder fields. The $a_{\text {nap }}(\lambda)$ presented varied magnitudes (Figure 5b), with BAR1 higher than BB2, BB1, IBI1, NAV1, NAV2, BAR2, and IBI2. The $a_{c d o m}(\lambda)$ also did not show the upstream to downstream decay, with magnitudes varying in descending order from BAR1, BAR2, IBI1, IBI2, BB2, BB1, NAV2, and NAV1 (Figure 5c).
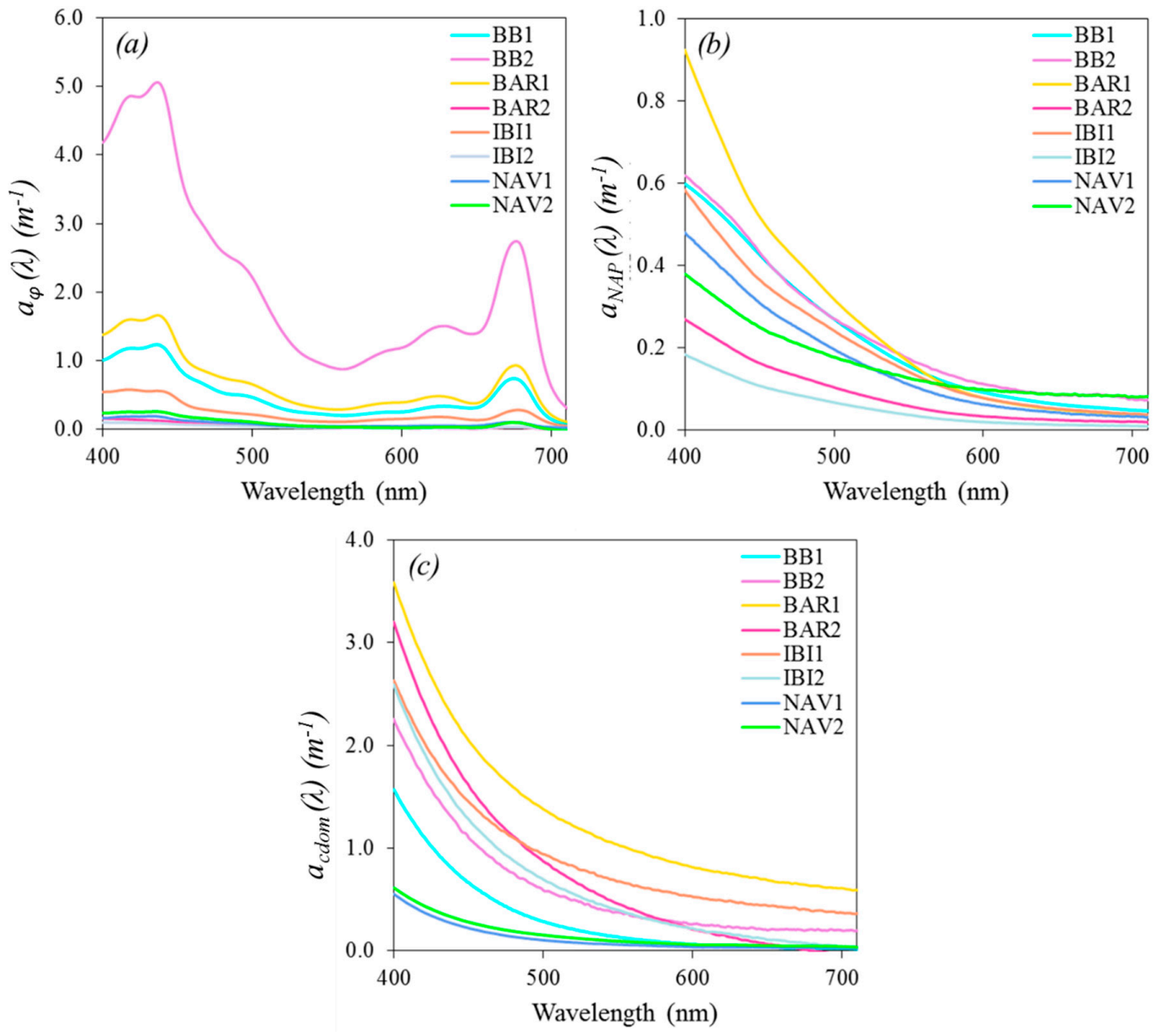

Figure 5. Average absorption spectra of (a) $a_{\phi}$; (b) $a_{n a p}$; (c) $a_{c d o m}$ from all of the field surveys and respective optically active compounds (OACs).

\subsection{Absorption Budget}

The ternary diagram represented the OAC's absorption contributions to the absorption itself $\left(a_{t-w}(\lambda)\right)$ without water. Then, the diagrams were plotted in Figure 6 for the specific wavelengths of the Operational Land Imager sensor onboard ongoing Landsat 8 (OLI/Landsat-8): 443 nm, 482 $\mathrm{nm}, 560 \mathrm{~nm}$, and $655 \mathrm{~nm}$. The OLI sensor was used because its images are suitable for inland water applications due to the spatial resolution and revisit time [21]. 

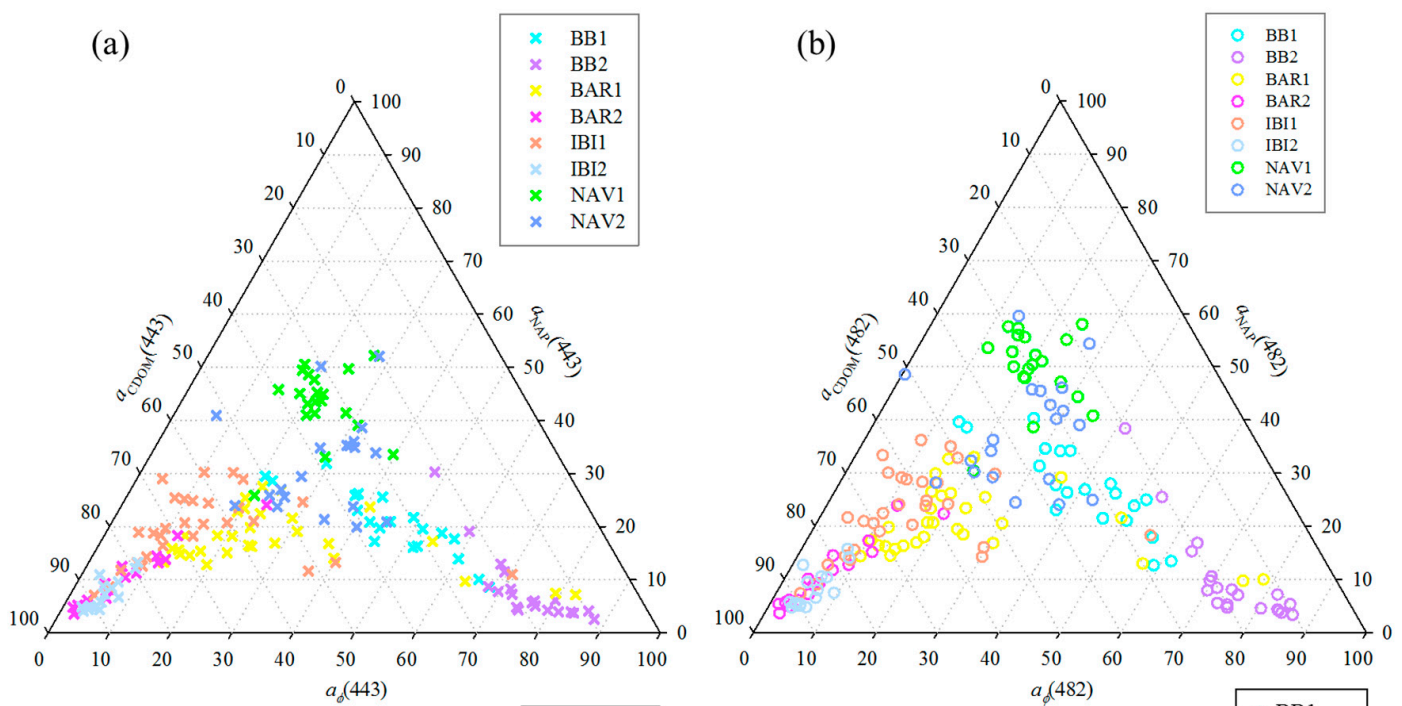

(c)
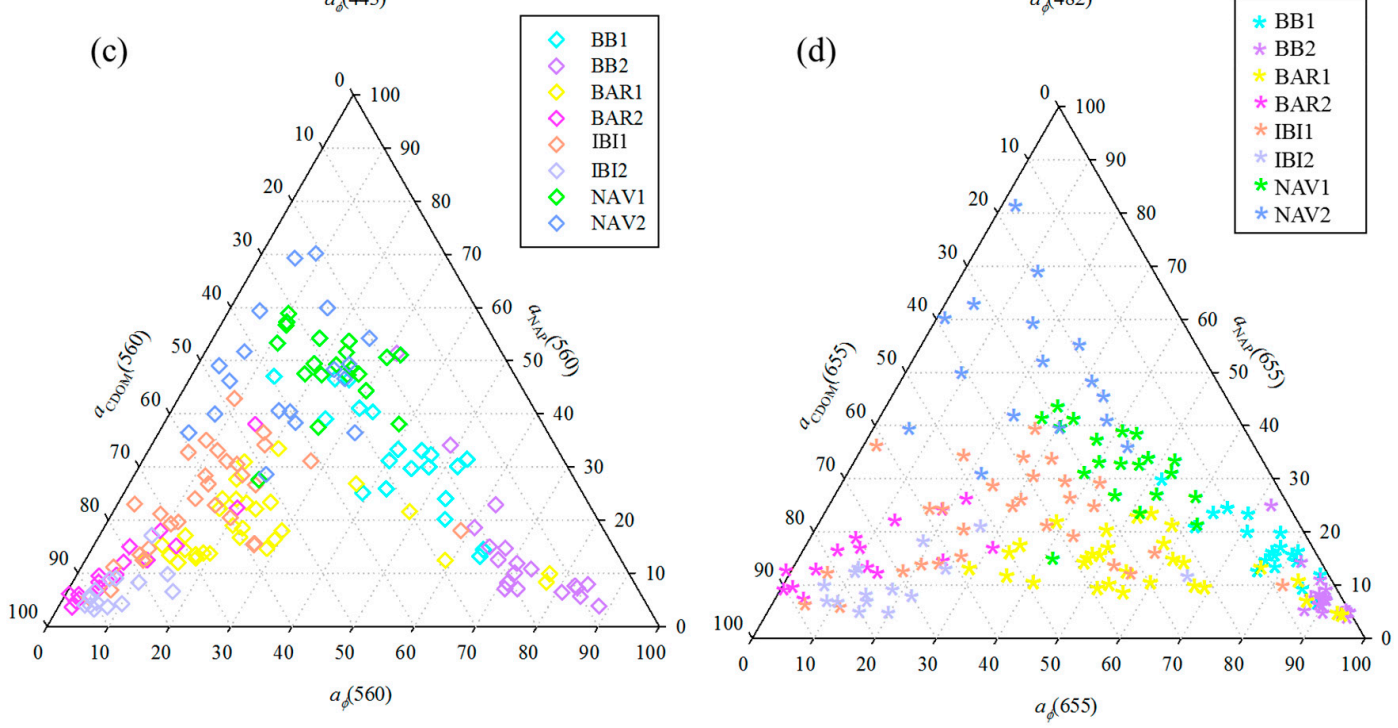

Figure 6. Ternary diagrams showing the contribution (\%) of absorption coefficients to $a_{t-w}$ at (a) $443 \mathrm{~nm}$; (b) $482 \mathrm{~nm}$; (c) $560 \mathrm{~nm}$; and (d) $655 \mathrm{~nm}$ from all of the field surveys (BB1, BB2, BAR1, BAR2, IBI1, IBI2, NAV1, and NAV2).

The $a_{t-w}(443)$ (Figure 6a) showed different OAC contributions in each reservoir. Overall, in BAR (both field studies) and IBI (both field studies), the major contributor was CDOM (averages of $53.3 \%, 82.74 \%, 64.9 \%$, and $87.30 \%$ for BAR1, BAR2, IBI1, and IBI2). In BB (both field studies), we identified a marked contribution from phytoplankton absorption (BB1: 20.7-67.8\%; BB2: 48.1-87.9\%). NAV1 presented a major influence of NAP (43.2\%), whereas NAV2 presented high contributions from CDOM and NAP (39.4\% and $31.7 \%$, respectively). Considering the region of Photosynthetically Active Radiation (PAR) from 400-nm to 700-nm range and including the contribution of water to the total absorption, we maintain our findings for almost all of the field works, excepting NAV2, where water presented a dominance of $41 \%$ against $30 \%$ from NAP (Table 3 ). 
Table 3. Mean contribution of $a_{c d o m}, a_{\phi}, a_{n a p}$, and $a_{w}$ to $a_{t}$ within the $400-700 \mathrm{~nm}$ of range (PAR region).

\begin{tabular}{ccccccccc}
\hline & & & \multicolumn{7}{c}{ Field Sites } & & \\
& BB1 & BB2 & BAR1 & BAR2 & IBI1 & IBI2 & NAV1 & NAV2 \\
\hline$a_{\text {cdom }}$ & $26.1 \%$ & $19.0 \%$ & $\mathbf{4 0 . 5} \%$ & $\mathbf{7 2 . 6 \%}$ & $\mathbf{4 9 . 0} \%$ & $\mathbf{7 2 . 1 \%}$ & $22.8 \%$ & $18.6 \%$ \\
$a_{\phi}$ & $\mathbf{4 3 . 0 \%}$ & $\mathbf{6 8 . 9} \%$ & $37.4 \%$ & $5.2 \%$ & $21.3 \%$ & $4.7 \%$ & $16.7 \%$ & $10.9 \%$ \\
$a_{\text {nap }}$ & $18.3 \%$ & $7.4 \%$ & $14.1 \%$ & $8.1 \%$ & $16.8 \%$ & $6.3 \%$ & $\mathbf{3 1 . 2} \%$ & $29.8 \%$ \\
$a_{w}$ & $12.6 \%$ & $4.7 \%$ & $8.0 \%$ & $14.1 \%$ & $12.9 \%$ & $16.9 \%$ & $29.3 \%$ & $\mathbf{4 0 . 7 \%}$ \\
\hline
\end{tabular}

The $a_{t-w}(482)$ (Figure $6 \mathrm{~b}$ ), showed a high contribution of $a_{\phi}$ to BB (BB1: $40.07 \%$ and BB2: $73.06 \%$ of averages). The $a_{c d o m}$ contribution was predominant in BAR1, BAR2, IBI1, and IBI2 (averages of $54.6 \%$, $82.5 \%, 63.5 \%$, and $86.2 \%$, respectively). NAP was dominant in NAV1 (30.4-58.0\%), whereas NAV2 presented a slightly higher $a_{\phi}$ contribution (37.8\%) compared to $a_{\text {nap }}(31.7 \%)$.

For the $a_{t-w}(560)$ (Figure $\left.6 \mathrm{c}\right), \mathrm{BB} 1$ increased the dominance of the $a_{\phi}\left(42 \%\right.$ on average) and $a_{\text {nap }}$ (32\% on average) contributions. BB2 presented higher $a_{\phi}$ contributions (31.5-95.7\%), and some samples showed a slight increase in NAP contributions. BAR1 presented a high CDOM contribution $(30.1-77.6 \%)$ with two samples that showed remarkable $a_{\phi}(\lambda)$ contributions (they also presented the highest $\mathrm{Chl}-a$ concentrations in the BAR dataset). BAR2 maintained a high contribution from CDOM (47.0-94.1\%). IBI1 showed a strong influence by CDOM (41.4-90.5\%), as well as IBI2 (74.3-91.8\%); BAR and IBI datasets were clustered toward the CDOM apex (Figure 6c). NAV1 has $a_{\text {nap }}$-dominant (contributions ranging between $28-70 \%)$ with one CDOM-dominated sample $\left(a_{c d o m}=51.6 \%\right)$. Overall, NAV2 conserved the high influence of $a_{\text {nap }}(28.6-70.2 \%)$, with one CDOM-dominated sample $\left(a_{\text {cdom }}=58 \%\right)$.

The $a_{t-w}(655)$ (Figure $6 \mathrm{~d}$ ) depicted a high influence by $a_{\phi}$ in BB1 (52.8-90.1\%) and BB2 (73.2-96.1\%). BAR1 was phytoplankton-dominant (30.0-95.2\%), with three samples that presented meaningful $a_{c d o m}$ contributions $\left(a_{\text {cdom }}(655)>50 \%\right)$, whilst BAR2 showed the predominance of CDOM (52.8-91.3\%). IBI1 and IBI2 were CDOM-dominant (with averages of $48.5 \%$ and $71.4 \%$, respectively), while there was one phytoplankton-dominated sample in IBI1 $\left(a_{\phi}(655)=58.7 \%\right)$, and another sample was displaced to the phytoplankton apex in IBI2 $\left(a_{\phi}(655)=82.6 \%\right)$. NAV1 presented a homogeneous distribution among all of the OACs, with a remarkable $a_{\text {nap }}$ contribution ( $30.5 \%$ on average), and a slight highlight of the $a_{\phi}$ contribution in some samples, which reached $60 \%$. NAV2 was mostly dominated by NAP $(34.0-79.4 \%)$.

\subsection{Light Absorption Variability from Upstream to Downstream}

To better represent the longitudinal variability of light absorption from upstream to downstream, the average values of $a_{\phi}, a_{n a p}, a_{c d o m}$, and $a_{t-w}$ at $443 \mathrm{~nm}$ are displayed in boxplot graphs (Figure 7). We considered $443 \mathrm{~nm}$ as a reference wavelength, due to its relation to dissolved organic matter concentration [39] and the marked Chl- $a$ pigment absorption feature $[4,40]$; furthermore, it is the central wavelength of the first OLI spectral band.

The light absorption decreases from upstream to downstream, following a similar pattern that was observed for OACs (see Figure 6). However, the absorption is very sensitive to the concentration of OACs at the time of the water sampling. There is an increase in the light absorption with higher concentrations and a decrease with lower concentrations. The $a_{c d o m}(443)$ data showed that the BAR reservoir has more $\mathrm{CDOM}$ in the water than the $\mathrm{BB}$ reservoir, although both reservoirs had similar Chl- $a$ concentrations. The $a_{\text {nap }}(443)$ showed the smallest longitudinal gradient of light absorption coefficients along the cascade. The $a_{t-w}(443)$ decreased from upstream to downstream, and showed that phytoplankton was the main contributor to $a_{t-w}(443)$. 

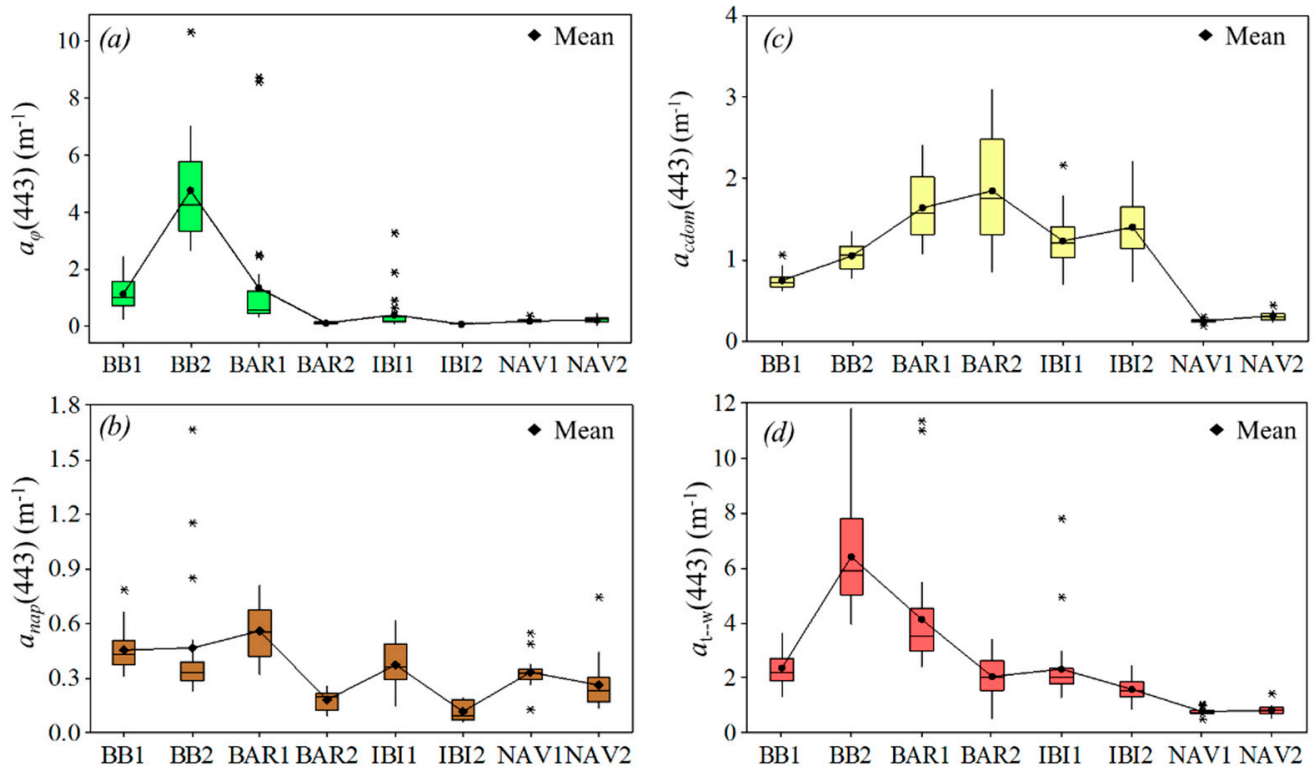

Figure 7. Boxplot of absorption coefficients at $443 \mathrm{~nm}$ obtained in all of the field campaigns: (a) $a_{\phi}(443)\left(\mathrm{m}^{-1}\right) ;(\mathbf{b}) a_{n a p}(443)\left(\mathrm{m}^{-1}\right) ;(\mathbf{c}) a_{c d o m}(443)\left(\mathrm{m}^{-1}\right) ;$ and $(\mathbf{d}) a_{t-w}(443)\left(\mathrm{m}^{-1}\right)$.

\section{Discussion}

Evaluating optical properties throughout inland water systems that showed extreme upstream gradients is not an easy task [41]. There many variables that affect the hydrodynamic of hydroelectrical reservoirs, such as the hydraulic residence time of water (and fluctuation of water level), land use and cover use of drainage basin, wind, rainfall rates, runoff, and internal properties, including temperature, incident solar radiation into the water surface, and nutrients, for instance [26,42]. It is already known that the absorption properties are proportional to the amount and diversity of optically active constituents within the water [5,43]; however, the relations along cascading reservoirs with substantially different characteristics were not fully investigated in the literature.

All of the fieldwork was carried out in dry seasons (except IBI1) and at similar wind speeds. According to Tundisi and Matsumura-Tundisi (1990) [44], water management leads to relatively high residence times during the dry seasons, and dry seasons normally present higher concentrations of Chl- $a$ and suspended matter, due to high nutrient loads and light availability [39]. The rainfall rates in BB did not vary too much when compared to the other fieldwork (Figure S5a) and presented high levels of Chl- $a$. The main cause can be attributed to the incident solar radiation onto the surface (Figure S5b) in BB2, which is not as predominant in IBI2 and BAR2 (for field studies that were carried out in June 2017).

The water residence times in each reservoir were: 30-180 days in BB; seven to 24 days in BAR; 25-41 days in IBI; and 46 days (on average) in NAV. Similar Chl- $a$ concentrations for BAR1/IBI1 and BAR2/IBI2 are related to the low residence time similar length (BAR is almost $70 \mathrm{~km}$ long, and IBI is $48 \mathrm{~km}$ ) and comparably meanders along their course. Therefore, this suggests that the same environmental effects affect both reservoirs, since they show similar physical characteristics. They are geographically near (they are in sequence within the cascade), and they are located in drainage basins with similar developed activities [45]. The higher Chl- $a$ concentrations in the BAR and IBI reservoirs are a consequence of local discharges from respective tributaries. It is also reasonable to suggest that the high retention time and the proximity to urban areas, which are responsible for the high discharges of nutrients and optimal conditions for phytoplankton growth, are the main causes of the high Chl- $a$ concentrations found in BB [4]. The low nutrient concentrations in NAV are responsible for the lack of phytoplankton development as much as bottom vegetation, due to river bottom nutrients, and the deeper euphotic zone [22,27]. 
The most variable qualitative parameters were PIM (in BB1, BB2, BAR2, NAV1, and NAV2 field studies) and Chl- $a$ concentration (in BAR1 and IBI1 field studies), with outliers of Chl- $a$ concentrations in BAR1 and IBI1 (Figure 2b). Outliers in BAR1 were the samples that were located in front of the Ribeirão Grande River, which is the tributary that receives wastewater discharges from Bauru city [31], which did not have domestic sewage treatment at the time of the fieldwork (Figure 1f). The outliers in IBI1 are located in the convergence zone between the Jacaré-Guaçu River and the Claro River (Figure 1g), which are the main tributaries of the IBI reservoir. These results suggest the existence of regional nutrient inputs from tributaries, which modify the regional characteristics within the BAR and IBI reservoirs. Temperature and $\mathrm{pH}$ did not present gradients along the TCSR (Table 1); however, higher $\mathrm{pH}$ values were accomplished by higher Chl- $a$ concentrations, which can be caused by intense phytoplankton activity, which removes $\mathrm{CO} 2$ from aquatic systems, and changes the $\mathrm{pH}$, to values normally higher than 7.0.

Regarding the water quality parameters in TCSR, the Chl- $a$ concentrations are highly related to $\operatorname{POM}(\mathrm{r}=0.94)$, and POM is highly related to SPM $(\mathrm{r}=0.99)$. The inorganic fraction (PIM) demonstrated a weak relationship with SPM $(r=0.67)$; such a decrease can be the consequence of the NAV reservoir, which is an inorganic-dominated environment [3]. The variations of organic-to-inorganic particulate matter from upstream to downstream reservoirs are depicted in Figure S1a, and demonstrated changes in the composition of the water quality parameters. In this respect, it is also possible to note a qualitative change with high concentrations of SPM and Chl- $a$ in the BB and BAR reservoirs, and low concentrations in NAV and IBI (Figure S1a,b).

Based on the organic to inorganic changes throughout the cascade, the results suggested higher $a_{\phi}(\lambda)$ magnitudes in the upstream reservoirs, and lower $a_{\phi}(\lambda)$ magnitudes in the downstream reservoirs. Such a trend was observed when the absorption spectrum curves were evaluated (Figure 5a). As opposed to the phytoplankton and NAP absorption curves, the $a_{c d o m}$ spectra were investigated due to the CDOM absorption effects on the available light for primary production [5].

The sources of colored DOM can be either autochthonous resulting from phytoplankton degradation that increases CDOM concentrations, or allochthonous resulting from carbon matter carried by the surrounding terrestrial basin drainage [46-48]. Considering the amount of energy sampled during the field studies (Figure S5b), we can note a trend in the relationships between high incident solar radiation and low levels of CDOM (represented by $a_{c d o m}(443 \mathrm{~nm})$ ) in NAV and BB (both field studies). The inverse is also validated: low levels of incident solar radiation and high levels of $a_{\text {cdom }}(443 \mathrm{~nm})$ were observed in BAR (both field studies) and IBI2. This trend is the result of the photochemical degradation of carbon organic matter due to light exposure, resulting in CDOM decreases [41,49]. The exception, IBI1, presented high levels of CDOM accompanied by high levels of incident solar radiation, which indicates that the main source of carbon organic matter was high rainfall in July 2016 (Figure 1c). These high levels of CDOM could be the main factor that replaces photodegraded CDOM with terrestrial organic matter from the drainage basin and tributaries [47].

The $a_{\text {cdom }}(443)$ from the entire cascade ranged from $0.21 \mathrm{~m}^{-1}$ to $3.17 \mathrm{~m}^{-1}$ (Table 2), which is similar to other published studies for aquatic systems [12,16,31,50-52]. The highest $a_{\text {cdom }}$ magnitudes were found in BAR1 and IBI1 (sampled curve in Figure 5c). The highest $a_{c d o m}$ curve in IBI1 was obtained at the same sampling location that presented the highest Chl- $a$ concentration in the IBI1 dataset. Additionally, this sample is located near the Environmental Protection Area of Ibitinga, which is an area with high forest coverage and bog lake formations, resulting from wetlands of tributaries (Jacaré-Guaçu and Jacaré-Pepira Rivers, Figure 1g). More detailed information can be found in Figure S6.

The exponential shape of a $a_{c d o m}$ described in terms of $S_{c d o m}$ showed a narrow range between $0.006 \mathrm{~nm}^{-1}<S_{\text {cdom }}<0.020 \mathrm{~nm}^{-1}$ in the TCSR. The $S_{\text {cdom }}$ showed an inverse proportional relation to its molecular weight, represented by $a_{c d o m}(443)$ (Kirk, 1994). The low values of $S_{c d o m}$ implied a high molecular weight of CDOM, whilst high values of $S_{c d o m}$ implied a low molecular weight $[38,53]$. Such 
an inverse relationship between $S_{c d o m}$ and $a_{c d o m}(443)$ can be related to the CDOM photochemical degradations from phytoplankton [54,55].

With the aim of investigating the sources of CDOM, we plotted $a_{\text {cdom }}(443)$ against Chl- $a$ concentrations (Figure S3). The plots can indicate whether CDOM was derived from autochthonous material (phytoplankton photobleaching) or from allochthonous material (riparian vegetation loads and runoff discharges) [56]. The results showed that at least one field campaign from each reservoir presented a significant statistical relationship between Chl- $a$ and $a_{c d o m}(443)$ (BB1, BAR2, IBI2, and NAV2). Nevertheless, the relationships changed between the field studies, which suggested that the CDOM origin varied. Moreover, the BB2 and BAR1 fieldworks did not show statistical relationships, even with high $\mathrm{Chl}-a$ concentrations, demonstrating that $\mathrm{CDOM}$ production is not dependent on the trophic status encountered within the aquatic system; BB and BAR are considered eutrophic environments.

The Chl- $a$ concentrations, accessory pigments, and the different physiology states of phytoplankton assemblages are the main factors that modify the intensity and spectral position of features in $a_{\phi}(\lambda)[9,15,57,58]$. Due to the existence of absorption peaks and their spectral positions, it is possible to infer the types of phytoplankton and pigments encountered in a sample $[5,58]$.

The $a_{\phi}(\lambda)$ peaks near $620 \mathrm{~nm}$ are related to phycocyanin, which is a pigment that is commonly present in cyanobacteria $[59,60]$. BB and BAR exhibited such features in almost all of the $a_{\phi}(\lambda)$ curves. Previous studies have related the dominance of cyanobacteria to phytoplankton assemblages in such reservoirs [26,27]. At approximately $443 \mathrm{~nm}$, the accessory pigments $(\mathrm{Chl}-b, c)$ and Chl- $a$ are the major contributors to $a_{\phi}(\lambda)$, whereas peaks at $675 \mathrm{~nm}$ result from Chl- $a$ plus phaeophytin pigments [57]. The features near $443 \mathrm{~nm}$ and $675 \mathrm{~nm}$ are remarkably observed in the $a_{\phi}(\lambda)$ curves obtained in BB (both field studies), BAR1, and IBI1; these features are less remarkable in NAV (both field studies), and disappear in BAR2 and IBI2 (Figure 4). A shoulder near $490 \mathrm{~nm}$, which is encountered in some spectral curves in BB (both field studies), BAR1, and IBI1 indicates the presence of carotenoids in phytoplankton pigments [61]. The reduction in Chl- $a$ concentrations directly affects the peaks near $440 \mathrm{~nm}$ and $675 \mathrm{~nm}$ in the $a_{\phi}$ curves (Figure 4), which are mainly in BAR1 and compared to those in BAR2 and IBI2. The total absorption is also influenced by such decay, and demonstrates the relationship between phytoplankton production and the spectral absorption of available energy. The feature near $440 \mathrm{~nm}$ represented the pigment accessories of phytoplankton (alpha and beta carotene), while the $675-\mathrm{nm}$ feature represented Chl- $a, b$, or $c$ pigments. The variability of features observed in samples from different reservoirs indicate the species richness of the phytoplankton community along the cascade. Due to the different absorption peaks in $a_{\phi}(\lambda)$ from upstream to downstream caused by the high variability in Chl-a concentrations and package effects [62], it is not possible to categorize the reservoirs according to the dominance of certain types of phytoplankton assemblages per reservoir. Conversely, it is possible to identify a longitudinal gradient of $a_{\phi}(\lambda)$ magnitudes in TCSR (Figure 5a), as observed for Chl- $a$ concentrations (Figure 2).

The $a_{\text {nap }}(\lambda)$ curves showed the iron oxides features between 450-550 nm [63] in BAR, IBI, and NAV fieldwork (Figure 4), which is consistent with the sandy soil formation in the drainage basin in the BAR and IBI reservoirs $[64,65]$, and demonstrated the influence of sand extraction activities observed in the NAV reservoir during the field studies. The highest and lowest $a_{\text {nap }}(\lambda)$ average curves (Figure $5 \mathrm{~b}$ ) are related to the average PIM concentrations (Table 1), as observed in BAR1 $\left(2.30 \mathrm{mg} \cdot \mathrm{L}^{-1}\right)$ and IBI2 $\left(0.40 \mathrm{mg} \cdot \mathrm{L}^{-1}\right)$, respectively. The $a_{\text {nap }}(\lambda)$ magnitudes depend on the concentration and type of particles $[66,67]$. Despite the significant differences in $S_{\text {nap }}$ in the fieldwork, these values are too small to hypothesize a water classification as a function of $S_{\text {nap }}$, such as the classification made in African reservoirs [16].

The evaluation of the absorption contribution of each OAC to $a_{t-w}$ made by a ternary diagram allowed for an understanding of the optical features in each reservoir. The ternary diagram is considered to be a tool for water classification, due to sampling distributions along the three axes (Case 1 or Case 2-type [68]). It is not our intention to classify the waters of the TCSR, but rather to 
properly understand what happens in the absorption coefficients along the cascade. Overall, the results indicated that the BAR and IBI reservoirs are CDOM-dominated environments, except for samples with high Chl- $a$ concentrations (higher than $700 \mathrm{mg} \cdot \mathrm{m}^{-3}$ ). The CDOM-dominance was conserved through the spectra (at $443 \mathrm{~nm}, 482 \mathrm{~nm}, 560 \mathrm{~nm}$, and $655 \mathrm{~nm}$ ) for the BAR and IBI fieldwork. BB (both field studies) is a phytoplankton-dominated environment, whilst NAV (both field studies) was identified as an NAP-dominated environment. Based on the average amount of contributions from each field, the reservoirs showed specific OAC dominances that were not wavelength dependent.

Considering $443 \mathrm{~nm}$ as a reference wavelength for plotting the absorption coefficient variation along the cascade (Figure 7), we observed a slight decrease in absorption from upstream to downstream, mainly in $a_{t-w}(443)$. Furthermore, phytoplankton absorption acted as the major contributor of $a_{t-w}(443)$, and showed the same decreasing trend encountered for OAC concentrations (Figure 2). The increasing dominance of CDOM in the BAR and IBI (Figure 6c) showed a relevant enrichment of CDOM within these reservoirs. Considering that $\mathrm{CDOM}$ is the colored fraction of dissolved organic matter (DOM), and DOM is an important fraction of dissolved organic carbon (DOC) in inland waters, CDOM can be used as a useful indicator of DOM and DOC [69,70]. Therefore, the CDOM dominance in BAR and IBI indicated high DOM and DOC concentrations, caused by internal production, in BAR2 and IBI2 (Figure S3), and terrestrial sources as in IBI1, due to the runoff discharges driven by watershed contributions.

\section{Conclusions}

Understanding and interpreting bio-optical properties, such as IOPs, further the understanding of the underwater light field, and are essential to bio-optical modeling developments and accurate water quality monitoring applications. The present results allowed an analysis of the dynamics of a cascading reservoir system, showing the continuous longitudinal gradient of optical absorptions and OACs in TCSR. Variations of the magnitude of OACs affect the light absorption coefficients, mainly $a_{\phi}$ and $a_{t-w}$. From upstream to downstream, the TCSR presented a slight decrease for the NAP and CDOM absorption coefficients, and they showed more susceptibility to allochthonous effects.

$a_{c d o m}$ was the highly variable parameter within the cascade, mainly in the BAR and IBI reservoirs. The $a_{c d o m}$ spectra did not show a decaying trend along TCSR; instead, it presented low magnitudes in BB and NAV, and major magnitudes in IBI and BAR. The different magnitudes of the $a_{c d o m}$ curves among the samples collected within the same reservoir indicate additional sources of CDOM throughout the aquatic systems; in other words, the tributaries and activities in the nearby areas affected the optical properties within reservoirs as much as the water flow from previous reservoirs. NAP absorption presented a less remarkable decaying trend from upstream to downstream, with high variations in the BAR and IBI fieldwork that can result from the contribution of runoff sediments.

The longitudinal gradient of $a_{\phi}$ is proportional to the Chl- $a$ concentration throughout the cascade, and directly influences $a_{t-w}$, despite the individual optical dominance for each reservoir. BB is a phytoplankton-dominated environment; BAR and IBI are CDOM-dominant environments, and NAV is an NAP-dominant environment. Some exceptions to the dominance of OAC were found in the specific sampling locations that showed distinct Chl- $a$, SPM, or $a_{c d o m}$ values compared to the entire dataset. In these cases, the highest absorption contribution within the reservoir changed accordingly to the most expressive OAC.

The insights from this work demonstrated a longitudinal gradient of absorption coefficients that were directly affected by OAC variations throughout the TCSR. Moreover, CDOM and NAP are essential to watershed contributions as much as the internal characteristics (such as residence time, incident solar radiation, and so forth). Furthermore, the land use and land cover in watersheds provide nutrient enrichments and pollution discharges within the reservoirs, and are reflected by OACs in specific locations, which affect the absorption coefficients. These local variations highlight the needs of local management to identify the main sources of higher OAC concentrations. The absorption variability found in TCSR confirms the challenges in retrieving OAC concentrations using a unique 
bio-optical model for the entire cascade. In contrast, our results highlighted the presence of a total absorption gradient and the strong influence of phytoplankton absorption on the total absorption along the aquatic continuum. Further analysis in a longer time series might provide temporal absorption coefficient datasets in TCSR and support strategies for bio-optical modeling in different optical conditions.

Supplementary Materials: The following are available online at http:/ /www.mdpi.com/2073-4441/11/2/229/s1.

Author Contributions: Conceptualization, E.A. and N.B.; methodology, E.A., N.B., F.W., T.R.; software, A.d.C.; validation, N.B., A.C.C.G. and C.A.; formal analysis, N.B., A.C.C.G. and T.R.; investigation, N.B.; resources, E.A.; data curation, N.B., F.W., T.R., A.d.C., A.C.C.G. and C.A.; writing-N.B.; writing-review and editing, E.A., F.W., A.d.C. and C.A.; visualization, N.B.; supervision, funding acquisition and project administration, E.A.

Funding: This research was funded by São Paulo Research Foundation - FAPESP, grant numbers 2012/19821-1 and 2015/21586-9; and National Counsel of Technological and Scientific Development-CNPq (Project numbers: 400881/2013-6 and 472131/2012-5).

Acknowledgments: The authors thank to FAPESP Projects aforementioned. The authors also thank the Coordination for the Improvement of Higher Education Personnel (CAPES) for scholarship, and Professor Edivaldo D. Velini and staff from FCA/UNESP for allowing the use of their laboratory facilities.

Conflicts of Interest: The authors declare no conflict of interest.

\section{References}

1. Lee, Z.; Carder, K.L.; Arnone, R.A. Deriving inherent optical properties from water color: A multiband quasi-analytical algorithm for optically deep waters. Appl. Opt. 2002, 41, 5755-5772. [CrossRef] [PubMed]

2. Odermatt, D.; Gitelson, A.; Brando, V.E.; Schaepman, M. Review of constituent retrieval in optically deep and complex waters from satellite imagery. Remote Sens. Environ. 2012, 118, 116-126. [CrossRef]

3. Rodrigues, T.; Alcântara, E.; Watanabe, F.; Bernardo, N.; Rotta, L.; Imai, N. Spatial and temporal variations of the inherent optical properties in a tropical cascading reservoir system. Model. Earth Syst. Environ. 2016, 2, 86. [CrossRef]

4. Watanabe, F.; Mishra, D.R.; Astuti, I.; Rodrigues, T.; Alcântara, E.; Imai, N.; Barbosa, C. Parametrization and calibration of a quasi-analytical algorithm for tropical eutrophic waters. ISPRS J. Photogramm. Remote Sens. 2016, 12, 28-47. [CrossRef]

5. Kirk, J. Light and Photosysnthesis in Aquactic Ecosystems, 2nd ed.; Cambridge University Press: Cambridge, UK, 1994.

6. Bricaud, A.; Morel, A.; Louis, P. Absorption by dissolved organic matter of the sea (yellow substance) in the UV and visible domains. Limnol. Oceanogr. 1981, 26, 43-53. [CrossRef]

7. Bricaud, A.; Babin, M.; Morel, A.; Claustre, H. Variability in the chlorophyll-specific absorption coefficients of natural phytoplankton: Analysis and parameterization. J. Geophys. Res. 1995, 100, 13321-13332. [CrossRef]

8. Bricaud, A.; Morel, A.; Babin, M.; Allali, K.; Claustre, H. Variations of light absorption by suspended particles with chlorophyll $a$ concentration in oceanic (case 1) waters: Analysis and implications for bio-optical models. J. Geophys. Res. 1998, 103, 31033-31044. [CrossRef]

9. Babin, M.; Stramski, D.; Ferrari, G.M.; Claustre, H.; Bricaud, A.; Obolensky, G.; Hoepffner, N. Variations in the light absorption coefficients of phytoplankton, nonalgal particles, and dissolved organic matter in coastal waters around Europe. J. Geophys. Res. 2003, 108. [CrossRef]

10. Gokul, E.A.; Palanisamy, S.; Sundarabalan, B.; Sahay, A.; Chauhan, P. Modelling the inherent optical properties and estimating the constituents' concentrations in turbid and eutrophic waters. Cont. Shelf Res. 2014, 84, 120-138. [CrossRef]

11. Shaju, S.S.; Minu, P.; Srokanth, A.S.; Ashraf, P.M.; Vijayan, A.K.; Meenakumari, B. Decomposition study of in vivo phytoplankton absorption spectra to identify the pigments and phytoplankton group in complex case 2 waters of coastal Arabian Sea. Oceanol. Hydrobiol. Stud. 2017, 44, 282-293. [CrossRef]

12. Vishnu, P.S.; Shaju, S.S.; Tiwari, S.P.; Menon, N.; Nashad, M.; Joseph, C.A.; Raman, M.; Hatha, M.; Prabhakaran, M.P.; Mohandas, A. Seasonal variability in bio-optical properties along the coastal waters of Cochin. Int. J. Appl. Earth Obs. Geoinf. 2018, 66, 184-195. [CrossRef] 
13. Das, S.; Hazra, S.; Giri, S.; Das, I.; Chanda, A.; Akhand, A.; Maity, S. Light absorption characteristics of chromophoric dissolved organic matter (CDOM) in the coastal waters of northern Bay of Bengal during winter season. Indian J. Geo Mar. Sci. 2017, 46, 884-992.

14. Ferreira, A.; Ciotti, A.M.; Giannini, M.F.C. Variability in the light absorption coefficients of phytoplankton, non-algae particles, and colored dissolved organic matter in a subtropical bay (Brazil). Estuar. Coast. Shelf Sci. 2014, 139, 127-136. [CrossRef]

15. Campbell, G.; Phinn, S.R.; Daniel, P. The specific inherent optical properties of three subtropical and tropical water reservoirs in Queensland, Australia. Hydrobiologia 2011, 658, 233-252. [CrossRef]

16. Matthews, M.W.; Bernard, S. Characterizing the absorption properties for remote sensing of three small optically-diverse South African reservoirs. Remote Sens. 2013, 5, 4370-4404. [CrossRef]

17. Alcântara, E.; Watanabe, F.; Rodrigues, T.; Bernardo, N.; Rotta, L.; Carmo, A.; Curtarelli, M.; Imai, N. Field measurements of the backscattering coefficient in a cascading reservoir system: First results from Nova Avanhandava and Barra Bonita Reservoirs (São Paulo, Brazil). Remote Sens. Lett. 2016, 7, 417-426. [CrossRef]

18. Moore, T.; Dowell, M.D.; Bradt, S.; Verdu, A.R. An optical water type framework for selecting and blending retrievals from bio-optical algorithms in lake and coastal waters. Remote Sens. Environ. 2014, 143, 97-111. [CrossRef]

19. Shen, Q.; Li, J.; Zhang, F.; Li, J.; Li, W.; Zhang, B. Classification of several optically complex waters in China using in situ remote sensing reflectance. Remote Sens. 2015, 7, 429-440. [CrossRef]

20. Spyrakos, E.; O’Donnell, R.; Hunter, P.D.; Miller, C.; Scott, M.; Simis, S.G.; Neil, C.; Barbosa, C.C.; Binding, C.E.; Bradt, S.; et al. Optical types of inland and coastal waters. Limnol. Oceanogr. 2018, 63, 846-870. [CrossRef]

21. Pahlevan, N.; Lee, Z.; Wei, J.; Schaaf, C.B.; Schott, J.R.; Berk, A. On-orbit radiometric characterizations of OLI (Landast-8) for applications in aquatic remote sensing. Remote Sens. Environ. 2014, 154, 272-284. [CrossRef]

22. Rodrigues, T.; Alcântara, E.; Watanabe, F.; Imai, N. Retrieval of Secchi Disk Depth from reservoir using a semi-analytical scheme. Remote Sens. Environ. 2017, 198, 213-228. [CrossRef]

23. Muow, C.B.; Greb, S.; Aurin, D.; DiGiacomo, P.M.; Lee, Z.; Twardowski, M.T.; Binding, C.; Hu, C.; Ma, R.; Moore, T.; et al. Aquatic color radiometry remote sensing of coastal and inland waters: Challenges and recommendations for future satellite missions. Remote Sens. Environ. 2013, 160, 15-30. [CrossRef]

24. Palmer, S.C.J.; Kutser, T.; Hunter, P.D. Remote sensing of inland waters: Challenges, progress and future directions. Remote Sens. Environ. 2015, 157, 1-7. [CrossRef]

25. Shi, L.; Mao, Z.; Wu, J.; Liu, M.; Zhang, Y.; Wang, Z. Variations in spectral absorption properties of phytoplankton, non-algae particles and Chromophoric Dissolved Organic Matter in Lake Qiandaohu. Water 2018, 9, 352. [CrossRef]

26. Barbosa, F.A.R.; Padisák, J.; Espíndola, E.L.G.; Borics, G.; Rocha, O. The cascading reservoirs continuum concept (CRCC) and its application to the river Tietê-basin, São Paulo State, Brazil. In Theoretical Reservoir Ecology and its Application; Tundisi, J.G., Straskraba, M., Eds.; International Institute of Ecology, Academy of Sciences and Backhuys Publishers: São Carlos, Brazil, 1999; pp. 425-437.

27. Smith, W.S.; Espíndola, E.L.G.; Rocha, O. Environmental gradients in reservoirs of the medium and low Tietê River: Limnological differences trough the habitat sequence. Acta Limnol. Bras. 2014, 16, 73-88. [CrossRef]

28. Frascareli, D.; Cardoso-Silva, S.; Mizael, J.D.; Rosa, A.H.; Pompeo, M.L.M.; Doval, J.C.L.; Moschini, C.V. Spatial distribution, bioavailability, and toxicity of metals in surface sediments of tropical reservoirs, Brazil. Environ. Monit. Assess 2018, 190, 199. [CrossRef] [PubMed]

29. Dellamano-oliveira, M.J.; Vieira, A.A.H.; Rocha, O.; Colombo, V.; Sant'Anna, C.L. Phytoplankton taxonomic composition and temporal changes in a tropical reservoir. Fund Appl. Limnol. 2008, 171, 27-38. [CrossRef]

30. Londe, L.R.; Novo, E.M.L.M.; Barbosa, C.; Araujo, C.A.S. Water residence time affecting phytoplankton blooms: Study case in Ibitinga Reservoir (São Paulo, Brazil) using Landsat/TM images. Braz. J. Biol. 2016, 76, 664-672. [CrossRef] [PubMed]

31. Cairo, C.T.; Barbosa, C.C.F.; Novo, E.M.L.M.; Calijuri, M.C. Spatial and seasonal variation in diffuse attenuation coefficients of downward irradiance at Ibitinga Reservoir, São Paulo, Brazil. Hydrobiologia 2017, 784, 265-282. [CrossRef]

32. Rodrigues, T.W.P.; Guimarães, U.S.; Rotta, L.H.; Watanabe, F.S.; Alcântara, E.; Imai, N.N. Sampling design in reservoirs based on Landsat-8/OLI images: A case study in Nova Avanhandava reservoir (São Paulo State, Brazil). Bol. Ciênc. Geod. 2016, 22, 304-323. [CrossRef] 
33. APHA (American Public Health Association); AWWA (American Water Works Association); WEF (Water Environmental Federation). Standard Methods for the Examination of Water and Wastewater, 20th ed.; APHA; AWWA; WEF: Washington, DC, USA, 1998.

34. Golterman, H.L. Developments in Water Science 2. Physiological Limnology: An Approach to the Physiology of Lake Ecosystems; Elsevier: Amsterdam, The Netherlands, 1975.

35. Smith, R.C.; Baker, K.S. Optical properties of the clearest natural waters (200-800 nm). Appl. Opt. 1981, 20, 177-184. [CrossRef] [PubMed]

36. Tassan, S.; Ferrari, G.M. An alternative approach to absorption measurement of aquatic particles retained on filters. Limnol. Oceanogr. 1995, 40, 1358-1368. [CrossRef]

37. Tassan, S.; Ferrari, G.M. Measurement of light absorption by aquatic particles retained on filters: Determination of the optical path length amplification by the 'transmittance-reflectance' method. J. Plankton Res. 1998, 20, 1699-1709. [CrossRef]

38. Twardowski, M.S.; Boss, E.; Sullivan, J.M.; Donaghay, P.L. Modeling the spectral shape of absorption by chromophoric dissolved organic matter. Mar. Chem. 2004, 89, 69-88. [CrossRef]

39. Alcântara, E.; Bernardo, N.; Watanabe, F.; Rodrigues, T.; Rotta, L.; Carmo, A.; Shimabukuro, M.; Gonçalves, S.; Imai, N. Estimating the CDOM absorption coefficient in tropical inland waters using OLI/Landsat-8 images. Remote Sens. Lett. 2016, 7, 661-670. [CrossRef]

40. Cetinic, I. Phytoplankton: Optical Constituents of the Ocean. Available online: http:/ /www.oceanopticsbook. info/view/optical_constituents_of_the_ocean/_phytoplankton\#searchResult1 (accessed on 5 September 2018).

41. Massicote, P.; Asmala, E.; Stedmon, C.; Markager, S. Global distribution of dissolved organic matter along the aquatic continuum: Across rivers, lakes and oceans. Sci. Total Environ. 2017, 609, 180-191. [CrossRef] [PubMed]

42. Straškraba, M. Retention time as a key variable of reservoir limnology. In Theoretical Reservoir Ecology and Its Applications; Tundisi, J.G., Straškraba, M., Eds.; International Institute of Ecology, Brazilian Academy of Sciences and Backhuys Publishers: São Carlos, Brazil, 1999; pp. 385-410.

43. Bukata, R.P.; Jerome, J.H.; Kondratyev, A.S.; Pozdnyakov, D.V. Optical Properties and Remote Sensing of Inland and Coastal Waters; CRC Press: Boca Raton, FL, USA, 1995.

44. Tundisi, J.G.; Matsumura-Tundisi, T. Limnology and eutrophication of Barra Bonita reservoir, S. Paulo State, Southern Brazil. Arch. Hydrobiol. Beih. 1990, 33, 661-676.

45. Periotto, N.A.; Tundisi, J.G. A characterization of ecosystems services, drives and values of two watersheds in São Paulo State, Brazil. Braz. J. Biol. 2018, 78, 397-407. [CrossRef] [PubMed]

46. Massicotte, P.; Frenette, J.-J. Spatial connectivity in a large river system: Resolving the sources and fate of dissolved organic matter. Ecol. Appl. 2011, 21, 2600-2617. [CrossRef]

47. Lambert, T.; Teodoru, C.R.; Nyoni, F.C.; Bouillon, S.; Darchambeau, F.; Massicotte, P.; Borges, A.V. Along-stream transport and transformation of dissolved organic matter in a large tropical river. Biogeosciences 2016, 13, 2727-2741. [CrossRef]

48. Martins, S.; Chokmani, K.; Alcântara, E.; Ogashawara, I.; El-Alem, A. Mapping the coloured dissolved organic matter absorption coefficient in a eutrophic reservoir using remotely sensed images. Inland Waters 2018, 8, 488-504. [CrossRef]

49. Vähätalo, A.V.; Wetzel, R.G. Photochemical and microbial decomposition of chromophoric dissolved organic matter during long (months-years) exposures. Mar. Chem. 2004, 89, 313-326. [CrossRef]

50. Zhang, Y.; Zhang, B.; Wang, X.; Li, J.; Feng, S.; Zhao, Q.; Liu, M.; Qin, B. A study of absorption characteristics of chromophoric dissolved organic matter and particles in Lake Taihu, China. Hydrobiologia 2007, 592, 105-120. [CrossRef]

51. Zhang, M.; Tang, J.; Dong, Q.; Song, Q.; Ding, J. Retrieval of total suspended matter concentration in the Yellow and East China Seas from MODIS imagery. Remote Sens. Envron. 2010, 114, 392-403. [CrossRef]

52. Riddick, C.A.L.; Hunter, P.D.; Tyler, A.N.; Vicente, V.M.; Horváth, H.; Kovács, A.W.; Vörös, L.; Preston, T.; Présing, M. Spatial Variability of absorption coefficient over a biogeochemical gradient in a large and optically complex shallow lake. J. Geophys. Res. 2015, 120, 7040-7066. [CrossRef]

53. Carder, K.L.; Steward, R.G.; Harvey, G.R.; Ortner, P.B. Marine humic and fulvic acids: Their effects on remote sensing of ocean chlorophyll. Limnol. Oceanogr. 1989, 34, 68-81. [CrossRef] 
54. Helms, J.R.; Stubbins, A.; Ritchie, J.D.; Minor, E.C.; Kieber, D.J.; Mopper, K. Absorption spectral slopes and slope ratios as indicators of molecular weight, source, and photobleaching of chromophoric dissolved organic matter. Limnol. Oceanogr 2008, 53, 955-969. [CrossRef]

55. Matsuoka, A.; Hooker, S.B.; Bricaud, A.; Babin, M. Estimating absorption coefficients of colored dissolved organic matter (CDOM) using a semi-analytical algorithm for southern Beaufort Sea Waters: Application to deriving concentrations of dissolved organic carbon from space. Biogeosciences 2013, 10, 917-927. [CrossRef]

56. Tilstone, G.H.; Lotliker, A.A.; Miller, P.I.; Ashraf, P.M.; Kumar, T.S.; Suresh, T.; Ragavan, B.R.; Menon, H.B. Assessment of MODIS-Aqua chlorophyll- $a$ algorithms in coastal and shelf waters of the eastern Arabian Sea. Cont. Shelf Res. 2013, 65, 14-26. [CrossRef]

57. Sathyendranath, S.; Lazzara, L.; Prieur, L. Variations in the spectral values of specific absorption of phytoplankton. Limnol. Oceanogr. 1987, 32, 403-415. [CrossRef]

58. Mobley, C.D. Light and Water: Radiative Transfer in Natural Water; Academic Press: San Diego, CA, USA, 1994.

59. Richardson, L.L. Remote sensing of algal bloom dynamics: A new research fuses remote sensing of aquatic ecosystems with algal accessory pigment analysis. Bioscience 1996, 46, 492-501. [CrossRef]

60. Mishra, S.; Mishra, D.R.; Lee, Z. Bio-optical inversion in highly turbid and cyanobacteria-dominated waters. IEEE Trans. Geosci. Remote 2014, 52, 375-388. [CrossRef]

61. Perkins, M.G.; Effler, S.W.; Strait, C.M. Phytoplankton absorption and the chlorophyll $a$-specific absorption coefficient in dynamic Onondaga Lake. Inland Waters 2014, 4, 133-146. [CrossRef]

62. Watanabe, F.S.Y.; Alcântara, E.H.; Rodrigues, T.W.P.; Bernardo, N.M.R.; Rotta, L.H.S.; Imai, N.N. Phytoplankton community dynamic detection from the chlorophyll-specific absorption coefficient in productive inland waters. Acta Limnol. Bras. 2017, 29, s2179-s2975. [CrossRef]

63. Estapa, M.L.; Boss, E.; Mayer, L.M.; Roesler, C.S. Role of iron and organic carbon in mass-specific light absorption by particulate matter from Louisiana coastal waters. Limnol. Oceanogr 2012, 57, 97-112. [CrossRef]

64. Souza, A.D.G.; Tundisi, J.G. Hidrogeochemical comparative study of the Jaú and Jacaré-Guaçu River watersheds, São Paulo, Brazil. (English). Rev. Bras. Biol. 2000, 60, 563-570. [CrossRef]

65. Tundisi, J.D.; Matsumura-Tundisi, T.; Pareschi, D.C.; Luzia, A.P.; von Haeling, P.H.; Frollini, E. The Tietê/Jacaré watershed: A case study in research and management. Estud. Av. 2008, 22, 159-172. [CrossRef]

66. Woźniak, S.B.; Meler, J.; Lednicka, B.; Zdun, A.; Stoń-Egiert, J. Inherent optical properties of suspended particulate matter in the southern Baltic Sea. Oceanologia 2011, 53, 691-729. [CrossRef]

67. Meler, J.; Ostrowska, M.; Ston-Egiert, J.; Zablocka, M. Seasonal and spatial variability of light absorption by suspended particles in the southern Baltic: A mathematical description. J. Mar. Syst. 2017, 170, 68-87. [CrossRef]

68. Prieur, L.; Sathyendranath, S. An optical classification of coastal and oceanic waters based on specific spectral absorption curves of phytoplankton pigments, dissolved organic matter, and other particulate materials. Limnol. Oceanogr. 1981, 26, 671-689. [CrossRef]

69. Cole, J.J.; Prairie, Y.T.; Caraco, N.F.; McDowell, W.H.; Tranvik, L.J.; Striegl, R.G.; Duarte, C.M.; Kortelainen, P.; Downing, J.A.; Middelburg, J.J.; Melack, J. Plumbing the Global Carbon Cycle: Integrating inland waters into the terrestrial carbon budget. Ecosystems 2007, 10, 175-185. [CrossRef]

70. Zhu, W.; Yu, Q.; Tian, Y.Q.; Becker, B.L.; Zheng, T.; Carrick, H.J. An assessment of remote sensing algorithms for colored dissolved organic matter in complex freshwater environments. Remote Sens. Environ. 2014, 140, 776-778. [CrossRef]

(C) 2019 by the authors. Licensee MDPI, Basel, Switzerland. This article is an open access article distributed under the terms and conditions of the Creative Commons Attribution (CC BY) license (http://creativecommons.org/licenses/by/4.0/). 